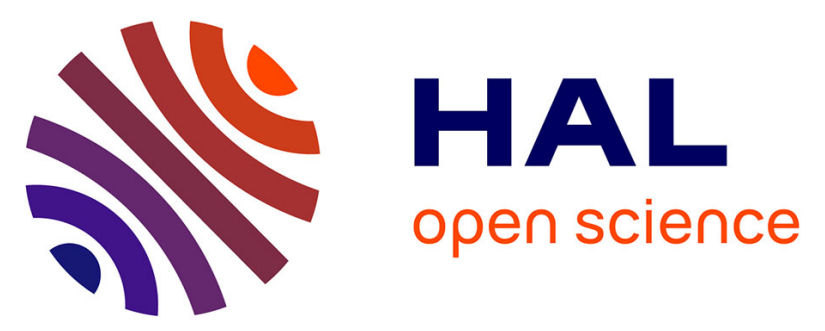

\title{
Low effect of phenanthrene bioaccessibility on its biodegradation in diffusely contaminated soil
}

\author{
M. Crampon, A. Cébron, F. Portet-Koltalo, S. Uroz, F. Le Derf, J. Bodilis
}

\section{To cite this version:}

M. Crampon, A. Cébron, F. Portet-Koltalo, S. Uroz, F. Le Derf, et al.. Low effect of phenanthrene bioaccessibility on its biodegradation in diffusely contaminated soil. Environmental Pollution, 2017, 225, pp.663-673. 10.1016/j.envpol.2017.03.053 . hal-01597866

\section{HAL Id: hal-01597866 https://hal.science/hal-01597866}

Submitted on 21 Jan 2022

HAL is a multi-disciplinary open access archive for the deposit and dissemination of scientific research documents, whether they are published or not. The documents may come from teaching and research institutions in France or abroad, or from public or private research centers.
L'archive ouverte pluridisciplinaire HAL, est destinée au dépôt et à la diffusion de documents scientifiques de niveau recherche, publiés ou non, émanant des établissements d'enseignement et de recherche français ou étrangers, des laboratoires publics ou privés.

\section{(1) (1) $\$$}

Distributed under a Creative Commons Attribution - NonCommercial - NoDerivatives| 4.0 


\section{Low effect of phenanthrene bioaccessibility on its biodegradation}

\section{2 in diffusely contaminated soil}

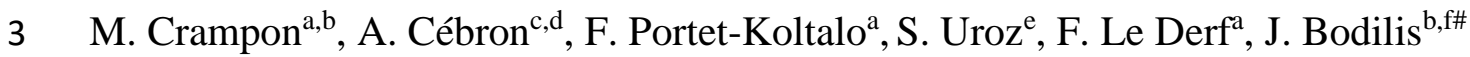

4

5 a COBRA UMR CNRS 6014, Université de Rouen-Normandie, 55 rue saint Germain, 27000 Evreux, France

6 b Laboratoire de Microbiologie Signaux et Microenvironnement, EA 4312, Université de Rouen, 76821 Mont Saint Aignan, France

7 c CNRS, LIEC UMR 7360, Faculté des Sciences et Technologies, BP70239, 54506 Vandoeuvre-lès-Nancy Cedex, France

$8{ }^{d}$ Université de Lorraine, LIEC UMR 7360, Faculté des Sciences et Technologies, BP70239, 54506 Vandoeuvre-lès-Nancy Cedex, France

9 e UMR 1138 INRA, centre de Nancy, Biogéochimie des Ecosystèmes forestiers, Route d'Amance, 54280 Champenoux, France

$10 \mathrm{f}$ Université de Lyon, France; CNRS, INRA, Ecole Nationale Vétérinaire de Lyon, and Université Lyon 1, UMR 5557 Ecologie Microbienne,

1143 boulevard du 11 novembre 1918, 69622 Villeurbanne cedex, France

13 Short title: Low effect of bioaccessibility on phenanthrene biodegradation in soil

\# Corresponding author: J. Bodilis, josselin.bodilis@univ-rouen.fr

15

Keywords: phenanthrene biodegradation; soil; bioaccessibility; DNA-SIP; rhamnolipids; 

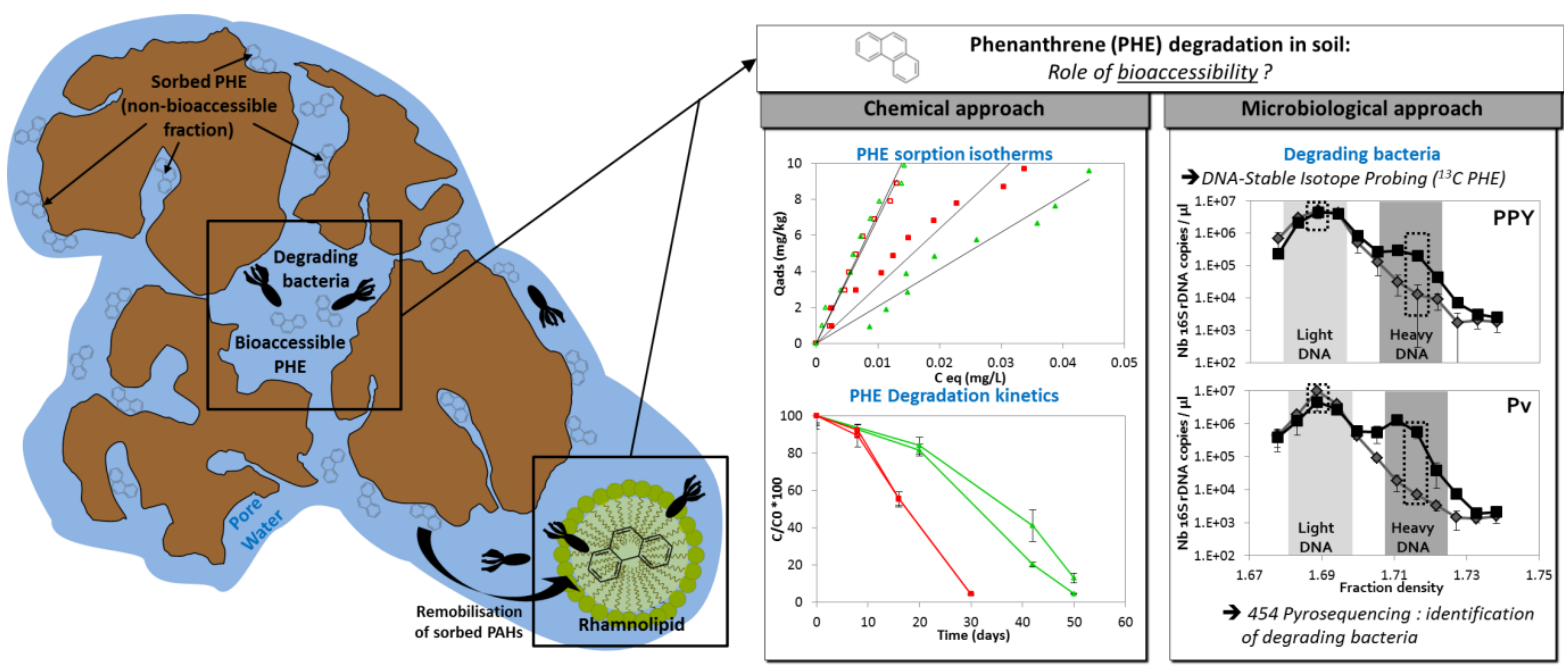

\section{Abstract}

This study focused on the role of bioaccessibility in the phenanthrene (PHE) biodegradation in diffusely contaminated soil, by combining chemical and microbiological approaches. First, we determined PHE dissipation rates and PHE sorption/desorption kinetics for two soils (PPY and Pv) presenting similar chronic PAH contamination, but different physico-chemical properties.

Our results revealed that the PHE dissipation rate was significantly higher in the Pv soil compared to the PPY soil, while PHE sorption/desorption kinetics were similar. Interestingly, increases of PHE desorption and potentially of PHE bioaccessibility were observed for both soils when adding rhamnolipids. Second, using ${ }^{13} \mathrm{C}$-PHE incubated in the same soils, we analysed the PHE degrading bacterial communities. The combination of stable isotope probing (DNA-SIP) and 16S rRNA gene pyrosequencing revealed that Betaproteobacteria were the main PHE degraders in the Pv soil, while a higher bacterial diversity (Alpha-, Beta-, Gammaproteobacteria and Actinobacteria) was involved in PHE degradation in the PPY soil. The amendment of biosurfactants commonly used in biostimulation methods (i.e. rhamnolipids) to the two soils clearly modified the PHE sorption/desorption kinetics, but had no significant impact on PHE degradation rates and PHE-degraders identity. These results demonstrated that 
increasing the bioaccessibility of PHE has a low impact on its degradation and on the functional populations involved in this degradation.

38

39

\section{Capsule}

41 The increase of the bioaccessibility level of phenanthrene has a low impact on its degradation 42 in diffusely contaminated soil. 


\section{Introduction}

Polycyclic aromatic hydrocarbons (PAHs) are ubiquitous carcinogenic organic contaminants, originating from multiple sources (i.e. biogenic, petrogenic and pyrogenic). Among them, human activities are responsible for the major releases into the environment, particularly through atmospheric deposition (Tobiszewski and Namieśnik, 2012). PAHs physico-chemical properties (high chemical stability, low vapor pressure, low aqueous solubility, high waterorganic carbon $\mathrm{K}_{\mathrm{oc}}$ partition coefficient) make them persistent in soils. However, this persistence is also strongly dependent on soil physico-chemical properties and soil microbial activities (Doyle et al., 2008).

In the case of diffuse contamination, soils are continuously exposed to low and repeated deposits of PAHs. In these soils, PAHs can be found in different soil compartments, depending on the age and history of the contamination. A small fraction of these PAHs is usually present in the soil aqueous phase, and is considered as directly accessible to microorganisms for degradation. The bioaccessible fraction is available to cross cellular membranes if the organism is present and has access to it, even after a period of time or through spatial rearrangements, whereas the bioavailable fraction is that is freely available to cross the organism's cellular membrane at a given time (Riding et al., 2013). The PAHs recently adsorbed on soil constituents are also generally directly accessible to microorganisms, while PAHs in contact with soil constituents for a longer time become poorly bioaccessible. A last fraction of PAHs can be strongly bound to soils, by slow diffusion into soil micropores. The strong sorption/sequestration mechanisms of PAHs to organo-mineral complexes eventually creates non-extractable bound-residues (Ahangar, 2010), considered as not bioaccessible (Semple et al., 2004). 
After adaptation and selection processes, the soil bacterial communities acquire the potential to biodegrade the bioaccessible PAH fraction (Haritash and Kaushik, 2009). Indeed, different bacterial strains isolated from various contaminated soils have been described as capable of degrading PAHs and of growing with PAHs as sole carbon source. These bacteria belong to different phyla or classes such as $\alpha$-, $\beta$ - and $\gamma$-Proteobacteria (Haritash and Kaushik, 2009; Jeon et al., 2006; Kim and Jeon, 2009; Niepceron et al., 2013), Bacteroidetes, Actinobacteria (Timmis et al., 2010) or Firmicutes (Wu et al., 2008).

The bioaccessibility factor depends on the physico-chemical properties of PAH compounds and on the soil properties (clays and organic matter contents and nature) (Brandli et al., 2008; Jonker et al., 2005; Mechlińska et al., 2009; Xia et al., 2010). Besides that, the bioavailability factor depends on the physiological and catabolic potential of soil microorganisms (Crampon et al., 2014). The combination of these complex processes determines the fate of PAHs in soils (Semple et al., 2004; Semple et al., 2003). Enhancement of PAH bioaccessibility in contaminated soils through addition of surfactants has already been reported (Ahn et al., 2008; Paria, 2008; Zhou et al., 2007; Zhou and Zhu, 2008). Biosurfactants (e.g. surfactants naturally produced by (micro)organisms) are more environmental friendly and interesting due to their low critical micellar concentration (CMC) and their lower toxicity for soil microorganisms than synthetic ones (Bustamante et al., 2012). Rhamnolipids, produced by Pseudomonas aeruginosa (Bordas et al., 2005), have been described for their ability to remobilize sorbed PAHs and to potentially enhance their biodegradation in slurry batches or column experiments (Bordas et al., 2005; Congiu and Ortega-Calvo, 2014). However, the real impact of these rhamnolipids on PAHs accessibility after direct treatment of contaminated soils remains to be determined.

In this context, the aim of this study was to determine the parameters mostly governing phenanthrene (PHE) degradation rates in diffusely contaminated soils. PHE was chosen as a 
model PAH representative of low molecular weight PAHs (2-3 fused aromatic rings). To address such an objective, two soil types (PPY and Pv) characterized by similar chronic PAH contamination, but different physico-chemical characteristics, were analyzed and compared. In each soil type, chemical and molecular biological methods were combined to investigate the fate of phenanthrene (PHE) by focusing on: (i) PHE accessibility, (ii) PHE degradation kinetics, and (iii) PHE-degrading bacterial diversity in relation to the amendment or not of rhamnolipids. PHE degradation was monitored using a microcosm approach during two months. In microcosm, PHE sorption isotherms with or without rhamnolipids were determined to estimate PHE accessibility. PHE degradation kinetics were determined using ${ }^{13} \mathrm{C}-\mathrm{PHE}$ and PHEdegrading bacterial populations were identified through DNA-Stable Isotope Probing (DNASIP) and 16S rRNA gene amplicon pyrosequencing.

\section{Materials and Methods}

\section{Soil sampling and soil analyses}

Soil samples were collected in the Seine river basin (France), which is a highly urbanized and industrialized location accounting for $40 \%$ of the French economic activity and including $33 \%$ of oil refining and $50 \%$ of river traffic. In spring 2014 , approximately $15 \mathrm{~kg}$ of soil $(0-15 \mathrm{~cm}$ depth) of two diffusely contaminated soil types (PPY and Pv) were sampled. PPY soil is an agricultural soil characterized by a permanent grassland and located near Yvetot (SeineMaritime department, 49 $\left.36^{\prime} 40.6^{\prime \prime} 0^{\circ} 44^{\prime} 10.7^{\prime \prime E}\right)$, at about $15 \mathrm{~km}$ from the Seine River. The PPY soil is classified as Luvisol according to the World Reference Base for soil resources (IUSS Working Group WRB 2006). The second soil type sampled (Pv) is located near Petiville (Seine Maritime department, 49 $25^{\prime} 54.0^{\prime \prime} 0^{\circ} 36 ' 25.4 " \mathrm{E}$ ) in the Seine river estuary, and is 
partially covered by young willow. This soil, periodically flooded, is classified as fluvic Gleysol according to the World Reference Base for soil resources.

After sampling, field-moist soils were sieved through a $5 \mathrm{~mm}$ mesh and stored at room temperature for 8 days for acclimation. Aliquots were stored at $-20^{\circ} \mathrm{C}$ for molecular characterization of the initial microbial communities in the two soil types before PAH spiking.

The natural background concentrations of PAHs in both soils were lower than $1 \mathrm{mg} \cdot \mathrm{kg}^{-1}$ for the sum of the 16 PAHs classified as priority by the US-Environmental Protection Agency (USEPA) (Table 1).

Pv and PPY soil organic matter (OM) was analyzed on dried crushed soils by RockEval 6 pyrolysis (Vinci Technologies, France) and S2 peak deconvolution (Sebag et al., 2006) was obtained using peakfit software (SigmaPlot, Systat) and the "Bulk Rock" method, as described previously (Crampon et al., 2014) (Table 1). Nature of clays in soils was analyzed by X-Ray diffraction (XRD) (Philips PW3040 diffractometer, France), as described previously (Crampon et al., 2014).

Soil pH was determined according to the French NF ISO 10-390 standard. Granulometry was analyzed according to the NF X31-107 standard. CEC (Cationic Exchange Capacity) was obtained following the French NF ISO 31-130 standard by the cobaltihexamine method. The analyses of $\mathrm{pH}$, texture and CEC were carried out at the LAS-INRA laboratory (Arras, France).

\section{Phenanthrene sorption isotherm determination}

Sorption isotherm experiments were performed for both soils as previously described (Groboillot et al., 2011), in the presence or not of rhamnolipids. Briefly, sorption reactors consisted in $4 \mathrm{~g}$ of soil sieved at $355 \mu \mathrm{m}$ and mixed with $40 \mathrm{~mL}$ deionized water in glass tubes under magnetic agitation. Reactors were incubated at $25^{\circ} \mathrm{C}$ along the experiment and $\mathrm{HgCl}_{2}$ (500mg. $\mathrm{L}^{-1}$ ) was added as a biocide at the beginning of the experiment to avoid bacterial 
degradation, which could decrease PHE concentration in water after many hours. PHE was then introduced in the reactors with a known volume of PHE stock solution (100 mg. $\mathrm{L}^{-1}$ in acetonitrile), to obtain a range of concentrations (from 0.1 to $1 \mathrm{mg} \cdot \mathrm{L}^{-1}$ ), below its limit of solubility in water (i.e. $\left.1.6 \mathrm{mg} . \mathrm{L}^{-1}\right)$. The volume of acetonitrile injected $(<1 \%$ of the total volume) was low enough to have no impact on PHE sorption, as previously studied (Groboillot et al., 2011). To evaluate the remobilization capacity of rhamnolipids, the biosurfactant (AGAE Technologies (USA), 90\% purity) was added as a powder in the reactors $5 \mathrm{~h}$ after the introduction of PHE, to a final concentration of $0.55 \mathrm{~g} . \mathrm{L}^{-1}$ (concentration ten times higher than its CMC of $0.05 \mathrm{~g} . \mathrm{L}^{-1}$ ) to ensure the formation of micelles in the aqueous phase. Five hours was chosen as the time to add the biosurfactant after PHE spiking because it was observed that a "quasi" plateau was reached for PHE sorption after this time (data not shown). Mixtures treated or not with rhamnolipids were stirred during $24 \mathrm{~h}$ at $25^{\circ} \mathrm{C}$ to be sure to reach thermodynamic equilibrium (time evaluated during preliminary tests) (Barnier et al., 2014). Thereafter, reactors were centrifuged at $7000 \mathrm{rpm}$ during $20 \mathrm{~min}$ to recover the aqueous phase. The concentration of PHE at equilibrium in the aqueous phase after $24 \mathrm{~h}\left(\mathrm{C}_{\mathrm{eq}}\right)$ was then measured after solid-phase extraction (SPE) and analysis using high-performance liquid chromatography coupled with fluorescence detector (HPLC-FLD) as developed, in the section below. As our systems were closed, PHE spiked at $\mathrm{t}_{0}$ was fully distributed between the water and the soil phases after $24 \mathrm{~h}$. So, the sorbed concentration $\left(\mathrm{C}_{\mathrm{ads}}\right)$ was deduced knowing the initial PHE concentration $\mathrm{C}_{\mathrm{o}}$, following the equation $\mathrm{C}_{\mathrm{ads}}=\mathrm{C}_{0}-\mathrm{C}_{\mathrm{eq}}$. The $\mathrm{K}_{\mathrm{d}}$ partition coefficients were then obtained from the slope of the isotherms.

\section{Phenanthrene dissipation kinetics}

Microcosms consisted of $4.5 \mathrm{~g}$ of dry equivalent fresh soil (90\%) and $0.5 \mathrm{~g}$ of dry sterilized (autoclaved at $120^{\circ} \mathrm{C}$ for 20 min) soil $\left(10 \%\right.$ ) spiked with ${ }^{12} \mathrm{C}$-PHE (purity > 98\%) or ${ }^{13} \mathrm{C}$-PHE 
(uniformly labeled ${ }^{13} \mathrm{C}_{14}, 99$ atom \%; Sigma-Aldrich), mixed in a hermetically-closed $100 \mathrm{~mL}$ sterile glass flask. A PHE solution was prepared in acetone and spiked to the dry sterilized soils in order to obtain a final PHE concentration of 3,000 mg. $\mathrm{kg}^{-1}$ of soil. The dry sterilized soil was mixed under an extractor hood for $24 \mathrm{~h}$ to homogenize the PHE distribution and to evaporate the remaining acetone. After one week of stabilization at ambient temperature, the dry PHE contaminated and sterilized soil was mixed with the wet native soil (humidity of 24.1 and $31.7 \%$ wt of fresh soil for PPY and Pv soils, respectively) and gently homogenized to obtain final soil microcosms contaminated with PHE (300 mg.kg ${ }^{-1}$ dw soil). This spiked PHE final concentration was 337-940 times higher than the sum of the 16 USEPA background PAHs (Table 1) and 2000-2857 times higher than the concentration of the native 2-3 aromatic ring PAHs. So we could reasonably consider that the main effects of PAHs on our studied systems were mainly due to the addition of PHE at $300 \mathrm{mg} \cdot \mathrm{kg}^{-1}$, and so the impact of co-metabolism was negligible in our study. It was decided to add the initial spiked dried sterilized soil (10\%) to the native wet soil (90\%) after contact time of only 7 days, in order to avoid PHE dissipation in the initial spiked soil. Soil water content of each microcosm was adjusted with distilled water to $70 \%$ of its water holding capacity. It corresponded to a total of $43.5 \mathrm{~g}$ and $49.1 \mathrm{~g}$ of water per 100 g soil for PPY and Pv soils, respectively. Rhamnolipids were added to distilled water to a final concentration of $300 \mathrm{mg} \cdot \mathrm{kg}^{-1} \mathrm{dw}$ soil into half of the microcosms. Rhamnolipids correspond to a mixture of mono and di-rhamnolipids (R90 product). So the concentration of the added biosurfactant was around $0.61-0.69$ g.L $\mathrm{L}^{-1}$ in the water fraction, which was near the concentration tested in sorption studies. The flasks were opened once a week in sterile conditions for 15 min to renew the atmosphere, and were incubated at $20^{\circ} \mathrm{C}$ in static mode in a dark room. Analyses of microcosms were carried out after $0,8,16$ and 30 days of incubation for Pv soil and after 0, 20, 42 and 50 days for PPY soil, based on the different PHE degradation rates evaluated through a preliminary experiment (data not shown). These different sampling 
times between the two soils were chosen in order to be able to compare the labeled DNA between the two soils (in terms of percentage of dissipated PHE), to potentially have the same quantity of ${ }^{13} \mathrm{C}$ possibly incorporated into the degrading bacteria DNA. All the microcosms were performed in triplicates giving a total of 96 microcosms (2 soils, with and without rhamnolipids, 4 incubation times, 3 replicates and with ${ }^{12} \mathrm{C}$ and ${ }^{13} \mathrm{C}$ PHE). The experimental protocol is available in supplementary materials (Fig. S1).

\section{Phenanthrene extraction and measurements}

All organic solvents were purchased from Fisher Scientific (Illkirch, France) and were of HPLC grade. PHE extractions from soils were performed using the microwave accelerated extraction (MAE; Mars X, CEM Corporation, USA) as described previously (Portet-Koltalo et al., 2008). For PHE degradation kinetics, two aliquots of 1.5-2 $\mathrm{g}$ of wet soil were taken from each of the three microcosms (in triplicates) at each time point. Then at each studied time, 6 sub-samples of a soil without biosurfactant and 6 sub-samples of the same soil amended with biosurfactant were dried $24 \mathrm{~h}$ at $35^{\circ} \mathrm{C}$ (to avoid the semi volatile PAH loss) and crushed separately. One g of each of the 6 sub-samples was extracted simultaneously using MAE technique in $20 \mathrm{~mL}$ of an acetone/toluene $50 / 50(\mathrm{v} / \mathrm{v})$ mixture at $130^{\circ} \mathrm{C}$ for $30 \mathrm{~min}$, at $1,200 \mathrm{~W}$. So for each studied time, extraction yields were obtained from a mean of 6 values. To determine the PAHs concentration in native soils, $10 \mathrm{~g}$ of crushed dried soil were processed using MAE technique, with $40 \mathrm{~mL}$ of the acetone/toluene 50/50 mixture, in the same conditions as described above. After filtration $(0.45 \mu \mathrm{m}$ Teflon filters; Fisher Scientific, France), extracts were evaporated to reach a volume of $1.5 \mathrm{~mL}$. An internal standard ( $10 \mu \mathrm{L}$ of perdeuterated PHE at $100 \mathrm{mg}$. $\left.\mathrm{L}^{-1}\right)$ was added to 990 $\mu \mathrm{L}$ of each extract before GC-MS analyses. Quantification analyses were performed using a 6850 gas chromatograph from Agilent (USA) fitted with a mass spectrometer (MS) detector (5975C, Agilent) and using a DB5-MS capillary column (60 m×0.25 mm inner diameter, film 
thickness $0.25 \mu \mathrm{m}$; J\&W Scientific, USA) according to Crampon et al. (Crampon et al., 2014). The mass detector (electron impact ionization $70 \mathrm{eV}$ ) operated in the selected ion monitoring (SIM) mode for better sensitivity. The detection and quantification thresholds, calculated respectively as 3 and 10 times the standard deviation of the blank sample noise, were 1.5 and 5 $\mu \mathrm{g} . \mathrm{L}^{-1}$, respectively. The mean recovery of PHE after MAE-GC-MS extraction and analysis was $90.0 \pm 7.0 \%(\mathrm{n}=5)$.

PHE extractions from aqueous media were done by SPE using Strata-X cartridges (Phenomenex, Le Pecq, France). After cartridge conditioning and sample percolation (PortetKoltalo et al., 2013), PHE was eluted with $5 \mathrm{~mL}$ methylene chloride, and was evaporated under nitrogen flow and recovered in $1 \mathrm{~mL}$ acetonitrile before HPLC analysis. PHE quantification was performed using a HPLC (Beckman Coulter, USA) coupled to a FLD (Prostar 363, Varian, USA) and using a $\mathrm{C}_{18}$ Envirosep PP column $(150 \times 4.6 \mathrm{~mm}, \mathrm{dp}=5 \mu \mathrm{m})($ Phenomenex, Le Pecq, France) according to Portet-Koltalo et al. (Portet-Koltalo et al., 2013). Detection and quantification limits, calculated respectively as 3 and 10 times the standard deviation of the sample noise, were evaluated as 0.4 and $1.3 \mu \mathrm{g} . \mathrm{L}^{-1}$, respectively. The mean recovery of PHE after SPE-HPLC-FLD extraction and analysis was 94.2 $\pm 1.2 \%(\mathrm{n}=5)$. Taking into account the concentration factor using SPE, the limit of quantification of PHE in the aqueous medium was 33 ng. $\mathrm{L}^{-1}$. So PHE was preferentially measured in the aqueous medium after sorption experiments because SPE-HPLC-FLD allowed us to reach lowest concentrations than using GC-MS and because of the highest accuracy of the method.

\section{${ }^{13}$ C labeled DNA isolation}

For DNA-based diversity analyses, samples were selected for further analysis according to the level of ${ }^{13} \mathrm{C}$ PHE degradation. Initial soils collected before spiking (triplicates) and soil samples collected during the experiment at 20\% (DT20) and 90\% of PHE degradation (DT90) were used 
for soil genomic DNA extractions using the PowerSoil DNA isolation kit (Mo-Bio

242 Laboratories) according to the manufacturer recommendations. Extracted DNA was quantified

243 using NanoDrop 2000 (Thermo Scientific) and samples were stored at $-20^{\circ} \mathrm{C}$ until analysis.

244 Heavy $\left({ }^{13} \mathrm{C}\right.$ labeled $)$ and light DNA $\left({ }^{12} \mathrm{C}\right)$ were separated according to the protocol described

245 by Neufeld et al. (Neufeld et al., 2007). Gradients were prepared using a CsCl solution (purity

$246 \geq 99 \%$; Sigma-Aldrich) with an initial density of ca 1.85. Gradient buffer and DNA sample were then added (for a final DNA quantity in the centrifuge tube of 5 to $10 \mu \mathrm{g}$ ) to obtain a final density of 1.725. Ultracentrifugations were carried out on a Beckman centrifuge (Optima L-80 $\mathrm{XP}$ ) with a vertical rotor Vti 65.2 (Beckman), at 42,400 rpm for $40 \mathrm{~h}$ at $20^{\circ} \mathrm{C}$, with maximal acceleration and no deceleration to avoid gradient disturbance. After centrifugation, tubes were fractionated in 12 density fractions that were weighed to check the gradient formation. DNA contained in each fraction was then precipitated using 2 volumes of polyethylene glycol ( 0.8 $1 \mathrm{~mL}), 1 \mu \mathrm{L}$ glycogen $(20 \mu \mathrm{g})$, centrifuged (13000g for $30 \mathrm{~min})$ and washed with $70 \%$ purified ethanol $(500 \mu \mathrm{L})$, and finally recovered in $30 \mu \mathrm{L}$ TE buffer $(10 \mathrm{mM}$ Tris- $\mathrm{HCl}$ and $1 \mathrm{mM}$ EDTA in deionized water) for further use.

On DNA recovered from each DNA fraction, the abundance of 16S rRNA genes was quantified using real-time quantitative PCR to determine the distribution of heavy and light DNA. Realtime PCR assays were performed in a $20 \mu \mathrm{L}$ final volume, as previously described (Cebron et al., 2008) using: $2 \mathrm{X}$ iQ SYBR Green Supermix (Bio-Rad), $0.4 \mu$ mol.L ${ }^{-1}$ of each 16S rDNA universal primers 968F and 1401R (Nubel et al., 1996), BSA (0.06\%), $0.2 \mu \mathrm{L}$ DMSO 261 (dimethylsulfoxyde), $0.08 \mu \mathrm{L} \mathrm{t4gp32}$ protein (MP-Biomedicals) and $1 \mu \mathrm{L}$ of DNA. The amplification was carried out with 40 cycles of four steps: $20 \mathrm{sec}$ at $95^{\circ} \mathrm{C}, 20 \mathrm{sec}$ at $56^{\circ} \mathrm{C}$, and $30 \mathrm{sec}$ at $72^{\circ} \mathrm{C}$ and $5 \mathrm{sec}$ at $82^{\circ} \mathrm{C}$ (Cebron et al., 2008). On similar DNA fractions, fungal $18 \mathrm{~S}$ rRNA genes were also quantified using real-time quantitative PCR (Thion et al., 2013) with the 265 previously described primer pairs Fung5f-FF390r (Lueders et al., 2004), but no enrichment of 
fungi was detected in heavy DNA fractions (Fig. S3) meaning that fungi were not significantly involved into PHE degradation because they did not incorporated ${ }^{13} \mathrm{C}$ in their DNA.

\section{Identification of phenanthrene-degrading bacteria}

Altogether, DNA from the 16 microcosm treatments (2 soil types, with and without rhamnolipids, at DT90, light and heavy DNA fractions $\mathrm{n}^{\circ} 3$ and 7 , from ${ }^{12} \mathrm{C}$ and ${ }^{13} \mathrm{C}$ incubations) and the two initial soils, in triplicate, were chosen for sequencing, resulting in 54 samples. Libraries of $16 \mathrm{~S}$ rRNA gene amplicons were prepared for 454 pyrosequencing after amplification using universal primers 27F (5' - AGA GTT TGA TCC TGG CTC AG - 3') and 533R (5' - TTA CCG CGG CTG CTG GCA C - 3'), extended at the 5' end by 10 bp multiplex identifiers (MIDs, Roche). Amplifications were done with GoTaq G2 Green Master Mix (Promega). The amplification step was carried out with 25 and 30 cycles $\left(30 \mathrm{sec}\right.$ at $95^{\circ} \mathrm{C}, 30$ sec at $60^{\circ} \mathrm{C}, 30 \mathrm{sec}$ at $72^{\circ} \mathrm{C}$ ) for microcosm and initial soil samples, respectively. After quality checking on agarose gel electrophoresis and quantification using NanoDrop, three independent PCR products per sample were pooled together to minimize PCR bias on sequencing, and an equimolar mixture was then prepared. Pyrosequencing was carried out using a GS FLX 454 (Beckman Coulter Genomics, Danvers, MA, USA) and produced 316.5 megabases corresponding to a total of 716,250 partial 16S rRNA gene sequences having a median size of 490 bp. Sequence analyses, i.e. reducing sequencing error, removing chimeras, grouping into OTUs, subsampling to 1000 sequences, SILVA database alignment, and classifying using the RDP reference files were performed using MOTHUR (version 1.36), as recommended by its author (Schloss et al., 2011). Following the trimming, we obtained 250 bp sequences from the forward primer (corresponding to the $\mathrm{V} 1$ and $\mathrm{V} 216 \mathrm{~S}$ rDNA regions). The alpha diversity of the samples was estimated using the Chao1 richness estimator and the nonparametric Shannon diversity index considering a same number of sequences for each sample (i.e. 1000 sequences). 


\section{Statistical analyses}

293

294

Statistical analyses (ANOVA, Student's t tests, Kruskall Wallis tests, Kolmogorov Smirnov tests), data analysis and Factorial Correspondence Analysis (FCA) on OTUs table, by using Bray-Curtis dissimilarity distance, were performed using XLStat software (version 2.01.16906, Addinsoft, Paris). Chao-1 and nonparametric Shannon diversity indexes were calculated on OTUs table, using MOTHUR (version 1.36). ADONIS tests were performed by using BrayCurtis dissimilarity distance (R software, version 3.1.2, VEGAN package).

\section{Nucleotide sequence accession numbers}

All 16S rRNA gene sequences have been submitted to the NCBI Short Read Archive under the Bioproject accession number PRJNA312913.

\section{Results}

\section{Physico-chemical properties of soils}

Soil analyses show that the two soils were very different (Table 1), with the PPY soil characterized by acidic and moderate nutrient conditions and the Pv soil characterized by alkaline and higher nutrient availability. For both soils, the major grain size fraction was coarse silt, representing more than $40 \%$ dry weight of the mineral fraction (Table 1). Although both particle size distributions were close, by comparison with the Shepard diagram (Shepard, 1954), the PPY and the Pv soils correspond to sandy silt clayey and silt soils, respectively. Concerning the clayey fraction, total clay content was significantly higher $(P<0.05$; Student's t test $)$ in the Pv soil (20.2\%) compared to the PPY (15.5\%), but the nature of clays was different (Table 1). 
For PPY soil, chlorites, illites and kaolinites (clays with the lower CEC, 10-40, 20-30 and 3-15 meq. $\mathrm{g}^{-1}$, respectively; Morel, 1996) were dominant whereas smectites (80 meq. $\mathrm{g}^{-1}<\mathrm{CEC}<150$ meq. $\mathrm{g}^{-1}$ ) were dominant in the Pv soil. Consequently, the CEC of the Pv soil was higher than that of the PPY soil, especially due to clay types.

Concerning total organic carbon content (TOC), the PPY was the richest soil (Table 1). Residual carbon ( $\mathrm{RC}$ ) was dominant in both soils compared to pyrolysable carbon (PC), showing that OM tended to be mature and resistant to pyrolysis, and could potentially strongly sorb PHE. The main OM fraction in PPY soil corresponded to biomacromolecules whereas mature geomacromolecules, that are higher PHE sorbents, were dominant in the Pv soil.

\section{Phenanthrene sorption and bioaccessibility}

PHE sorption isotherms (Fig. 1) were similar for the PPY and the Pv soils $(P>0.05$, Kolmogorov-Smirnov Test). In the low PHE concentration range, they can both be described by a linear partitioning model $\left(\mathrm{R}^{2}=0.965\right.$ and 0.981 for PPY and Pv soils, respectively) (Crampon et al., 2016). So $\mathrm{K}_{\mathrm{d}}$ values were calculated from the slopes of the linear part of the sorption isotherms. The $\mathrm{K}_{\mathrm{d}}$ partition coefficients were $718.7 \mathrm{~L} . \mathrm{kg}^{-1}$ and $695.5 \mathrm{~L}^{\mathrm{kg}} \mathrm{kg}^{-1}$ for the PPY and the $\mathrm{Pv}$ soils, respectively. Water/organic carbon partition coefficients $\mathrm{K}_{\mathrm{oc}}$ could be calculated from the $K_{d}$ values and the total organic carbon fraction $\left(f_{o c}\right)$, using the equation: $\mathrm{K}_{\mathrm{oc}}=\mathrm{K}_{\mathrm{d}} / \mathrm{f}_{\mathrm{oc}} . \log \mathrm{K}_{\mathrm{oc}}$ values were 4.58 and 4.73 for PHE in the PPY and the Pv soils, respectively. Increases of PHE desorption and potentially of PHE bioaccessibility were observed for both soils when adding rhamnolipids in the aqueous medium (Fig. 1). Indeed, $\mathrm{K}_{\mathrm{d}}$ values obtained in the presence of rhamnolipids were significantly lower (Student's t test, $P<$ 0.05) than those obtained without biosurfactant: $206.2 \mathrm{~L}_{\mathrm{kg}}{ }^{-1}$ and $318.7 \mathrm{~L} \cdot \mathrm{kg}^{-1}$ for the PPY and the Pv soils, respectively $\left(\mathrm{R}^{2}=0.959\right.$ and 0.929 for PPY and Pv soils, respectively). 
342 Although no marked lag phase was observed in our experimental conditions, PHE dissipation was slow at the beginning of the experiments. Only $20 \%$ of PHE was degraded during the first 8 and 20 days for the Pv and the PPY soils, respectively (Fig. 2). Then, PHE dissipation was faster in Pv soil compared to the PPY soil, as ca 90\% of PHE was dissipated in 16 days in the Pv soil, while 42 days were necessary in the PPY soil. The same trends were observed in a previous experiment (Crampon et al., 2014), aiming, inter alia, to follow the degradation of 7 selected PAHs in different soils with the same sampling terms.

Kinetics of PHE dissipation in the presence of rhamnolipids did not show any significant impact of surfactant addition compared to the controls ( $P>0.05$, Student's $t$ test; Fig. 2$)$.

\section{SIP experiment and ${ }^{13} \mathrm{C}$ labeled DNA isolation}

Total community $\left({ }^{12} \mathrm{C}\right)$ and active ${ }^{13} \mathrm{C}$-labeled PHE-degrading bacterial populations were studied at two incubation times corresponding to DT20 (time where 20\% PHE is dissipated) and DT90 (time where 90\% PHE is dissipated) for both soils: it corresponded to 8 and 16 days of incubation for the Pv soil and 20 and 42 days of incubation for the PPY soil (Fig. 2). For controls, DNA was analyzed from both ${ }^{12} \mathrm{C}$ and ${ }^{13} \mathrm{C}$ microcosms.

Quantitative PCR revealed a higher number of 16S rRNA gene copies in the lower densities $(<1.70)$ of the $\mathrm{CsCl}$ gradient, corresponding to light DNA (that should contain only ${ }^{12} \mathrm{C} \mathrm{DNA}$ )

(Fig. 3). For further analyses the fraction $n^{\circ} 3(d=1.689)$ was selected. Heavy DNA (that should contain all ${ }^{13} \mathrm{C}$ DNA) was recovered in the fractions with density ranging from 1.705 to 1.722 (Fig. 3). Higher numbers of $16 \mathrm{~S}$ rRNA gene copies in these heavy fractions collected from the ${ }^{13} \mathrm{C}$ microcosms corresponded to the active ${ }^{13} \mathrm{C}$-labeled PHE-degrading bacteria. For further analyses the fraction $\mathrm{n}^{\circ} 7(\mathrm{~d}=1.711)$ was selected. At DT20, the difference between the number of $16 \mathrm{~S}$ rRNA gene copies in the fraction $\mathrm{n}^{\circ} 7$ from ${ }^{12} \mathrm{C}$ and ${ }^{13} \mathrm{C}$ microcosms was only significant 
for Pv soil microcosms $\left(P<0.05\right.$, ANOVA test; Fig. S2). In PPY soil microcosms, no ${ }^{13} \mathrm{C}$ labeled DNA was detected at DT20. At DT90, significant differences $(P<0.05$, ANOVA test $)$ were observed between ${ }^{12} \mathrm{C}$ and ${ }^{13} \mathrm{C}$ microcosms, for both soils (Fig. 3). The amounts of $16 \mathrm{~S}$ rRNA gene copies in the heavy fraction of DNA were about 10 and 50 times higher for the ${ }^{13} \mathrm{C}$ microcosms than for the ${ }^{12} \mathrm{C}$ microcosms for the PPY and the Pv soils, respectively. Therefore, samples at DT90 were chosen for sequencing and analyzing the bacterial diversity. No significant difference was observed in the level of ${ }^{13} \mathrm{C}$ incorporation between microcosms with and without rhamnolipids (Fig. 3).

No significant difference in the number of fungal 18S rRNA gene copies was observed between ${ }^{12} \mathrm{C}$ and ${ }^{13} \mathrm{C}$ microcosms (Fig. S3), meaning that ${ }^{13} \mathrm{C}$ from PHE was not used as a growth carbon source by fungi.

\section{Characterization of bacterial communities and identification of PHE-degrading bacteria} 454-pyrosequencing was carried out on 54 soil samples, corresponding to the soils before spiking and the fractions from the DNA-SIP experiment. After de-noising, a total of 211,519 16S rRNA gene sequences were obtained, with an average number of 3,917 sequences per sample. Even if the rarefaction curves based on operational taxonomic units (OTUs; at 97\% identity) did not reach a plateau for the soils before spiking, the diversity corresponding to the labeled ${ }^{13} \mathrm{C}$ DNA (i.e. PHE-degrading populations) seemed to be well sampled (Fig. S4). Although species richness given by Chao1 index was slightly higher for the Pv soil comparatively to the PPY soil, no significant differences ( $\mathrm{P}>0.05$, Kruskall-Wallis test) of alpha diversity were observed between the two native soils (Table 2). Concerning the heavy fractions from the ${ }^{13} \mathrm{C}$ microcosms (fractions PPY/Pv_13C_Rh+/-_H in Table 2), the observed richness were lower than in the initial soil types or in controls, meaning that PHE-degrading bacteria represent only a small fraction of the total community in both soils. This finding is more 
pronounced for the $\mathrm{Pv}$ soil, meaning that a significantly smaller number of OTUs $(P<0.05$, Kruskall-Wallis test) was involved in PHE degradation.

Factorial correspondence analysis (Fig. 4) was performed using the 100 most represented OTUs (in each soil, separately) to highlight similarities and dissimilarities between replicates, sample conditions (soil before spiking, ${ }^{12} \mathrm{C}$ and ${ }^{13} \mathrm{C}$ microcosms, or with and without rhamnolipids) and DNA fractions (light and heavy). Whatever the soil type, the bacterial diversity retrieved from the heavy DNA fractions of ${ }^{13} \mathrm{C}$ microcosms was significantly different from the diversity found in the heavy DNA fractions of ${ }^{12} \mathrm{C}$ control microcosms $(P<0.01$; ADONIS test $)$. A specific analysis of the effect of rhamnolipids addition revealed no differences in each soil type between treatments with and without rhamnolipids, in both light or heavy fractions $(P>0.05$; ADONIS test). Notably, no differences appeared between the diversity in light DNA fractions from both ${ }^{12} \mathrm{C}$ and ${ }^{13} \mathrm{C}$ microcosms and the diversity of soils before spiking.

The analysis of the sequence distribution in the OTUs represented in the heavy DNA fractions from the ${ }^{13} \mathrm{C}$ labeled microcosms and having a significantly higher abundance than in the ${ }^{12} \mathrm{C}$ control microcosms allowed us to identify the main ${ }^{13} \mathrm{C}$-labeled PHE degrading bacteria (Table 3). Notably, this analysis revealed that the main PHE degraders identified were poorly represented in the initial soils (from $<0.01 \%$ to $0.29 \%$ of the total sequences, Table 3 ), as in the light and heavy fractions of the ${ }^{12} \mathrm{C}$ microcosms (from $<0.01 \%$ to $3.0 \%$ of the total sequences, data not shown).

The six OTUs, representing the active PHE degraders in the Pv soil, were identified as members of the Betaproteobacteria class, with a high proportion of the Rhodocyclaceae family and some Burkholderiales (including the Polaromonas genus). Concerning the PPY soil, members of a higher number of OTUs were involved in PHE degradation. The 13 OTUs representing the active PHE degraders belonged to Alpha-, Beta-, Gamma-Proteobacteria and Actinobacteria. Notably the OTUs Pv_PHE6 and PPY_PHE6 were both related to the Polaromonas genus 
(Table 3), and appeared phylogenetically close (Fig. S5). Moreover, OTUs Pv_PHE4 and PPY_PHE12 corresponded to the same OTU affiliated to the Rhodoferax genus (Table 3 and Fig. S5).

The relative abundance of some PHE degraders increased or decreased depending on the presence or absence of rhamnolipids, but only in the case of some of the low abundance PHE degraders (Table 3). Notably, the proportion of the two OTUs related to the Polaromonas genus was significantly higher in the presence of rhamnolipids in both soils. By contrast, when rhamnolipids were added, the relative proportion of sequences related to the Rhodoferax genus was significantly higher for the PPY soil $(P<0.05)$, whereas it tended be lower for the Pv soil $(P>0.05)$. Altogether, our results revealed that direct addition of rhamnolipids to soil has a limited effect on the active PHE degrading bacteria.

\section{Discussion}

PHE accessibility was assessed by studying different physico-chemical properties of soil, and by characterizing PHE sorption isotherms with or without rhamnolipids. Overall, the two soils considered were characterized by a similar OM content, but a high variation in their clay contents and natures. While total organic carbon content was slightly higher in the PPY soil, OM was dominated by mature geomacromolecules in the Pv soil (Table 1). This fraction of OM combines constituents naturally stable or stabilized by physico-chemical processes, residues of fires and some anthropogenic pollutants like soot, i.e. black carbon (Sebag et al, 2006). The higher content of this more mature, carbonaceous and crystallized fraction in Pv soil make it probably more prone to a stronger PHE sorption than the PPY soil. The characterization of OM maturation state in soils is important because binding energies and sorption properties towards PAHs increase over time (Ran et al., 2007). Indeed, PAHs sorption is generally lower and more reversible on fresh OM compared to aged OM because with ageing, the polar mixtures of 
biomolecules transforms into a more hydrophobic form with higher sorptive properties for

442 lipophilic organic compounds (Mechlińska et al., 2009). Moreover, both total clay contents and natures varied significantly between the two soil types considered. Chlorites, illites and

444

445

446 kaolinites were dominant in the PPY soil, whereas smectite was dominant in the Pv soil. Although clay is generally described as a parameter affecting less PAH sorption to soil particles compared to organic matter, it has to be considered here because of the potential impact on rhamnolipids (Delle Site, 2001; Hwang and Cutright, 2002). Indeed, it has been reported that sorption of rhamnolipids to soil is more strongly influenced by clay contents and nature than by $\mathrm{OM}$ : at low biosurfactant concentrations, that are relevant for enhancing organic contaminant biodegradation, clays and particularly kaolinite are the strongest sorbents for rhamnolipids (Ochoa-Loza et al., 2007). So clays could influence observed results on PHE remobilization.

Interestingly, despite these different physico-chemical properties and biodegradation kinetics, PHE sorption was found to be quite similar in the two soil types. These results are consistent with a previous study, where we showed that the bioaccessible fraction of PHE, estimated using a mild extraction method (extraction with hydroxypropyl- $\beta$-cyclodextrin) was close between these two soil types (Crampon et al., 2014). Furthermore, rhamnolipids addition increased PHE desorption in both soil types, but with a greater effect in the PPY soil. Although no consensus exists on the real positive or negative effect of rhamnolipids on PAH removal, several studies reported a strong impact of soil organic matter content and contamination ageing (Congiu and Ortega-Calvo, 2014; Szulc et al., 2014). Thus, the lowest PHE desorption from the Pv soil by rhamnolipids addition could be explained by higher contents of mature OM, smectites and kaolinite in the $\mathrm{Pv}$ soil. These soil constituents may enhance the formation of clay-humic complexes and thus contribute to a strong adsorption of PHE on these complexes. Moreover, these clay minerals increase the surface available for PAH as well as rhamnolipids sorption. 
The presence of higher contents of kaolinite in $\mathrm{Pv}$ soil (Table 1) can explain the strongest sorption of the biosurfactant on Pv soil, compared to PPY soil. Consequently, there may be less micelles in the soil solution to remobilize PHE and more additional sorption sites through rhamnolipids sorbed on soil aggregates (Ochoa-Loza et al., 2007; Zhou and Zhu, 2007). Although rhamnolipids significantly increased PHE desorption in the two soil types tested, addition of a biosurfactant had a limited impact on the PAH biodegradation efficiency (Fig. 2). While some studies report that surfactants may increase PAH biodegradation rates, others have shown that the effect of their application may be negligible (Laha and Luthy, 1991; Rouse et al., 1994; Tiehm, 1994; Tsomides et al., 1995). Indeed, Leonardi et al. (Leonardi et al., 2007) showed that when a soil is characterized by a low non-bioaccessible PAH fraction, addition of surfactant has a limited impact on the PAH biodegradation efficiency. Moreover, the effect of the surfactant could also depend on the identity of PAH-degrading bacteria involved (Allen et al., 1999). At last, we can also suppose that if rhamnolipids can partially desorb PAHs from soils, they can also desorb them from the surface of bacteria, which can lead to the decrease of their bioavailability while they increase their bioaccessibility.

More generally, other factors might explain the difference in degradation rate observed between the two soils. Indeed, the optimum $\mathrm{pH}$ range can be very variable depending on the type of soil and the PAH-degrading bacteria (Simarro et al., 2011). It could not be excluded that the basic Pv soil allowed a greater activity of the PAH-degrading bacteria than the acidic PPY soil. Moreover, difference in initial concentrations of nitrogen and carbon between the two soils may also affect the activity of the PAH-degrading bacteria (Teng et al., 2010). Temperature and toxicity of PAHs could also impact the biodegradation rate (Coover and Sims, 1987; Martin et al., 2012). Indeed, native high molecular weight PAHs (4-6 ring PAHs), which can be considered as the most toxic PAHs, were 2.5 times more concentrated in Pv soil than in PPY soil. However, it must be noted that they represent only $0.09-0.22 \%$ of the total amount of PAHs 
after PHE spiking, which is quite negligible. Interestingly, all the factors having a potential impact on the PHE degradation kinetics have in common to influence the physiology of the PAH-degrading bacteria.

In a second phase, we therefore studied the diversity of the PAH-degrading bacteria in order (i) to compare the PAH-degrading populations between these two soils and (ii) to evaluate the impact of a bioavailability variation on these degrading populations. The combination of ${ }^{13} \mathrm{C}$ labeled PHE and 16S rRNA gene amplicon pyrosequencing enabled us to identify the PHEdegrading bacterial communities in these two contrasted soil types.

Most of the PHE degraders identified in the two soil types belonged to the Proteobacteria phylum. Some members of the Alphaproteobacteria (Demaneche et al., 2004), Betaproteobacteria (Goyal and Zylstra, 1997; Laurie and Lloyd-Jones, 1999; Seo et al., 2009) and Gammaproteobacteria (Balashova et al., 2001; Ensley et al., 1982; Kiyohara et al., 1994; Resnick and Gibson, 1996) classes possess specific PAH dioxygenases involved in the catalysis of the initial aromatic ring oxidation (Cebron et al., 2008; Habe and Omori, 2003). Some OTUs belonging to these classes were found among PHE degraders in the PPY soil. In addition, one OTU of the PHE degraders belongs to the Mycobacterium genera (Actinobacteria) that has already been described as a good PAH degrader in soils (Timmis et al., 2010). Altogether, these PHE degraders were poorly represented in both initial soil bacterial communities, indicating that when soil PAH are diffusely concentrated, the PHE-degraders belong to the rare biosphere, but could rapidly become active when available PAHs enter the system.

The Pv soil presented a lower diversity of PHE degraders than the PPY soil, all belonging to the Betaproteobacteria. It was further shown that the abundance of Betaproteobacteria increased after three months of incubation in microcosms spiked with PHE, pyrene or a mix of seven PAHs, members of this bacterial class being largely described as capable of degrading PAHs (Jeon et al., 2003; Martin et al., 2012; Niepceron et al., 2013; Núñez et al., 2012; 
Singleton et al., 2006). Among the Betaproteobacteria class, sequences related to members of the Rhodocyclaceae family were the most represented in the ${ }^{13} \mathrm{C}$ fraction (more than $80 \%$ of the sequences), suggesting a major role in PHE degradation in the Pv soil. Interestingly, representatives of these taxa have also been described as able to degrade PAHs and to possess specific PAH RHD enzymes (Chemerys et al., 2014; Martin et al., 2012; Regonne et al., 2013; Singleton et al., 2006; Uhlik et al., 2012), and a cultivable member of this Rhodocyclaceae family that degrades PAHs has been recently sequenced (Singleton et al., 2015). The exceptional PAH degradation capacity of Rhodocyclaceae in various soils suggests classifying them as very efficient PHE degraders. Since previous representatives of this taxon have already been shown to efficiently degrade PAHs (Singleton et al., 2015), the Rhodocyclaceae family may be used as a bioindicator of soils with a high PHE degradation capacity. Moreover, cultivation-dependent analysis combined to genome sequencing should permit to further understand the functional role of the Rhodocyclaceae family in PAH degradation.

Interestingly, the diversity and the structure of the main PHE degraders seem only slightly impacted by rhamnolipids addition and no impact on the total bacterial community was detected. Such results suggest that the rhamnolipid amendment used in biostimulation processes is probably not used as carbon source, and may be a good alternative in term of toxicity for the soil bacterial communities compared to synthetic surfactants. However, its use for soils where bioaccessibility is not a limiting degradation parameter does not seem to be an advantage even if it improved PHE desorption in both soils.

\section{Conclusion}

By using chemical and microbiological methods, we demonstrated that the PHE bioaccessibility has a low impact on its degradation. Indeed, the difference in biodegradation rates we found between the two soils considered cannot be explained by a difference in 
bioaccessibility. Moreover, although the amendment of biosurfactants (i.e. rhamnolipids) did change the PHE sorption/desorption kinetics in the two soils tested, no significant impact on PHE degradation rates was detected. In addition, we showed that variation in biodegradation rate between these diffusely contaminated soils could be more explained by the differences in PHE-degrading populations, which presence and activities might be driven by physicochemical properties of the soils. Finally, we showed, for the first time to our knowledge, that rhamnolipids present a low toxicity for soil microorganisms as they do not modify the global bacterial diversity as well as the activity of the phenanthrene-degraders. In the future, it could be interesting to investigate the degradation kinetics of a mixture of PAHs (e.g. the 16 priority PAHs) with or without rhamnolipids and to identify the bacteria more particularly involved in the degradation of heavy high molecular weight PAHs.

\section{Acknowledgements}

The authors thank the "Région Haute Normandie" (France) for financial support through the Normandy SCALE research network (RESSOLV program). The authors thank the Ecogenomic plateform (INRA Nancy, France) for the using of the ultracentrifuge. The authors thank Jennifer Hellal for her help in proofreading the paper.

\section{Supporting information}

Five Figures (Figure S1, S2, S3, S4 and S5) are included in the supporting information.

\section{References}

Ahangar, A.G., 2010. Sorption of PAHs in the soil environment with emphasis on the role of soil organic matter: A review. World Applied Sciences Journal 11, 759-765. 
Ahn, C.K., Kim, Y.M., Woo, S.H., Park, J.M., 2008. Soil washing using various nonionic surfactants and their recovery by selective adsorption with activated carbon. Journal of Hazardous Matererials 154, 153-160.

Allen, C.C.R., Boyd, D.R., Hempenstall, F., Larkin, M.J., Sharma, N.D., 1999. Contrasting effects of a nonionic surfactant on the biotransformation of polycyclic aromatic hydrocarbons tocis-dihydrodiols by soil bacteria. Applied and Environmental Microbiology $65,1335-1339$.

Balashova, N., Stolz, A., Knackmuss, H., Kosheleva, I., Naumov, A., Boronin, A., 2001. Purification and characterization of a salicylate hydroxylase involved in 1-hydroxy-2naphthoic acid hydroxylation from the naphthalene and phenanthrene-degrading bacterial strain Pseudomonas putida BS202-P1. Biodegradation 12, 179-188.

Barnier, C., Ouvrard, S., Robin, C., Morel, J.L., 2014. Desorption kinetics of PAHs from aged industrial soils for availability assessment. Science of the Total Environment 470, 639-645.

Bordas, F., Lafrance, P., Villemur, R., 2005. Conditions for effective removal of pyrene from an artificially contaminated soil using Pseudomonas aeruginosa 57SJ rhamnolipids. Environmental Pollution 138, 69-76.

Brandli, R.C., Hartnik, T., Henriksen, T., Cornelissen, G., 2008. Sorption of native polyaromatic hydrocarbons (PAH) to black carbon and amended activated carbon in soil. Chemosphere 73, 1805-1810.

Bustamante, M., Durán, N., Diez, M.C., 2012. Biosurfactants are useful tools for the bioremediation of contaminated soil: a review. Journal of Soil Science and Plant Nutrition $12,667-687$.

Cebron, A., Norini, M.P., Beguiristain, T., Leyval, C., 2008. Real-Time PCR quantification of PAH-ring hydroxylating dioxygenase (PAH-RHDalpha) genes from Gram positive and 
Gram negative bacteria in soil and sediment samples. Journal of Microbiological Methods 73, 148-159.

591

592

593

594

595

596

597

598

599

600

601

602

603

604

605

606

607

608

609

610

611

612

Chemerys, A., Pelletier, E., Cruaud, C., Martin, F., Violet, F., Jouanneau, Y., 2014. Characterization of novel polycyclic aromatic hydrocarbon dioxygenases from the bacterial metagenomic DNA of a contaminated soil. Applied and Environmental Microbiology 80, 6591-6600.

Congiu, E., Ortega-Calvo, J.-J., 2014. Role of desorption kinetics in the rhamnolipid-enhanced biodegradation of polycyclic aromatic hydrocarbons. Environmental Science \& Technology 48, 10869-10877.

Coover, M.P., Sims, R.C., 1987. The effect of temperature on polycyclic aromatic hydrocarbon persistence in an unacclimated agricultural soil. Hazardous Waste and Hazardous Materials $4,69-82$.

Crampon, M., Bureau, F., Akpa-Vinceslas, M., Bodilis, J., Machour, N., Le Derf, F., PortetKoltalo, F., 2014. Correlations between PAH bioavailability, degrading bacteria, and soil characteristics during PAH biodegradation in five diffusely contaminated dissimilar soils. Environmental Science and Pollution Research 21, 8133-8145.

Crampon, M., Bodilis, J., Le Derf, F., Portet-Koltalo, F., 2016. Alternative techniques to HPCD to evaluate the bioaccessible fraction of soil-associated PAHs and correlation to biodegradation efficiency. Journal of Hazardous Materials 314, 220-229

Delle Site, A., 2001. Factors affecting sorption of organic compounds in natural sorbent/water systems and sorption coefficients for selected pollutants. A Review. Journal of Physical and Chemical Reference Data 30, 187-439.

Demaneche, S., Meyer, C., Micoud, J., Louwagie, M., Willison, J.C., Jouanneau, Y., 2004. Identification and functional analysis of two aromatic-ring-hydroxylating dioxygenases 

from a Sphingomonas strain that degrades various polycyclic aromatic hydrocarbons. Applied and Environmental Microbiology 70, 6714-6725.

Doyle, E., Muckian, L., Hickey, A.M., Clipson, N., 2008. Microbial PAH degradation. Advances in Applied Microbiology 65, 27-66.

617

Ensley, B.D., Gibson, D.T., Laborde, A.L., 1982. Oxidation of naphthalene by a multicomponent enzyme system from Pseudomonas sp. strain NCIB 9816. Journal of Bacteriology 149, 948-954.

Goyal, A., Zylstra, G., 1997. Genetics of naphthalene and phenanthrene degradation by Comamonas testosteroni. Journal of Industrial Microbiology and Biotechnology 19, 401407.

Groboillot, A., Portet-Koltalo, F., Le Derf, F., Feuilloley, M.J., Orange, N., Poc, C.D., 2011. Novel application of cyclolipopeptide amphisin: feasibility study as additive to remediate polycyclic aromatic hydrocarbon $(\mathrm{PAH})$ contaminated sediments. International Journal of Molecular Science 12, 1787-1806.

Habe, H., Omori, T., 2003. Genetics of polycyclic aromatic hydrocarbon metabolism in diverse aerobic bacteria. Bioscience, Biotechnology, and Biochemistry 67, 225-243.

Haritash, A., Kaushik, C., 2009. Biodegradation aspects of polycyclic aromatic hydrocarbons (PAHs): a review. Journal of Hazardous Materials 169, 1-15.

Hwang, S., Cutright, T.J., 2002. Impact of clay minerals and DOM on the competitive sorption/desorption of PAHs. Soil and Sediment Contamination: An International Journal $11,269-291$.

Jeon, C.O., Park, M., Ro, H.-S., Park, W., Madsen, E.L., 2006. The naphthalene catabolic (nag) genes of Polaromonas naphthalenivorans CJ2: evolutionary implications for two gene clusters and novel regulatory control. Applied and Environmental Microbiology 72, 10861095. 
Jeon, C.O., Park, W., Padmanabhan, P., DeRito, C., Snape, J.R., Madsen, E.L., 2003. Discovery of a bacterium, with distinctive dioxygenase, that is responsible for in situ biodegradation in contaminated sediment. Proceedings of the National Academy of Sciences 100, 1359113596.

Jonker, M.T., Hawthorne, S.B., Koelmans, A.A., 2005. Extremely slowly desorbing polycyclic aromatic hydrocarbons from soot and soot-like materials: evidence by supercritical fluid extraction. Environmental Science \& Technology 39, 7889-7895.

Kim, J.M., Jeon, C.O., 2009. Isolation and characterization of a new benzene, toluene, and ethylbenzene degrading bacterium, Acinetobacter sp. B113. Current Microbiology 58, 7075.

Kiyohara, H., Torigoe, S., Kaida, N., Asaki, T., Iida, T., Hayashi, H., Takizawa, N., 1994. Cloning and characterization of a chromosomal gene cluster, pah, that encodes the upper pathway for phenanthrene and naphthalene utilization by Pseudomonas putida OUS82. Journal of Bacteriology 176, 2439-2443.

Laha, S., Luthy, R.G., 1991. Inhibition of phenanthrene mineralization by nonionic surfactants in soil-water systems. Environmental science \& technology 25, 1920-1930.

Laurie, A.D., Lloyd-Jones, G., 1999. The phn genes of Burkholderia sp. strain RP007 constitute a divergent gene cluster for polycyclic aromatic hydrocarbon catabolism. Journal of Bacteriology 181, 531-540.

Leonardi, V., Šašek, V., Petruccioli, M., D’Annibale, A., Erbanová, P., Cajthaml, T., 2007. Bioavailability modification and fungal biodegradation of PAHs in aged industrial soils. International Biodeterioration \& Biodegradation 60, 165-170.

Lueders, T., Wagner, B., Claus, P., Friedrich, M.W., 2004. Stable isotope probing of rRNA and DNA reveals a dynamic methylotroph community and trophic interactions with fungi and protozoa in oxic rice field soil. Environmental Microbiology 6, 60-72. 
Martin, F., Torelli, S., Le Paslier, D., Barbance, A., Martin-Laurent, F., Bru, D., Geremia, R., Blake, G., Jouanneau, Y., 2012. Betaproteobacteria dominance and diversity shifts in the bacterial community of a PAH-contaminated soil exposed to phenanthrene. Environmental Pollution 162, 345-353.

Mechlińska, A., Gdaniec-Pietryka, M., Wolska, L., Namieśnik, J., 2009. Evolution of models for sorption of PAHs and PCBs on geosorbents. TrAC Trends in Analytical Chemistry 28, 466-482.

Neufeld, J.D., Vohra, J., Dumont, M.G., Lueders, T., Manefield, M., Friedrich, M.W., Murrell, J.C., 2007. DNA stable-isotope probing. Nature Protocols 2, 860-866.

Niepceron, M., Martin-Laurent, F., Crampon, M., Portet-Koltalo, F., Akpa-Vinceslas, M., Legras, M., Bru, D., Bureau, F., Bodilis, J., 2013. GammaProteobacteria as a potential bioindicator of a multiple contamination by polycyclic aromatic hydrocarbons (PAHs) in agricultural soils. Environmental Pollution 180, 199-205.

Nubel, U., Engelen, B., Felske, A., Snaidr, J., Wieshuber, A., Amann, R.I., Ludwig, W., Backhaus, H., 1996. Sequence heterogeneities of genes encoding 16S rRNAs in Paenibacillus polymyxa detected by temperature gradient gel electrophoresis. Journal of Bacteriology 178, 5636-5643.

Núñez, E.V., Valenzuela-Encinas, C., Alcántara-Hernández, R.J., Navarro-Noya, Y.E., LunaGuido, M., Marsch, R., Dendooven, L., 2012. Modifications of bacterial populations in anthracene contaminated soil. Applied Soil Ecology 61, 113-126.

Ochoa-Loza, F.J., Noordman, W.H., Jannsen, D.B., Brusseau, M.L., Maier, R.M., 2007. Effect of clays, metal oxides, and organic matter on rhamnolipid biosurfactant sorption by soil. Chemosphere 66, 1634-1642.

Paria, S., 2008. Surfactant-enhanced remediation of organic contaminated soil and water. Advances in Colloid and Interface Science 138, 24-58. 
Portet-Koltalo, F., Ammami, M.T., Benamar, A., Wang, H., Le Derf, F., Duclairoir-Poc, C., 2013. Investigation of the release of PAHs from artificially contaminated sediments using cyclolipopeptidic biosurfactants. Journal of Hazardous Materials 261, 593-601.

Portet-Koltalo, F., Oukebdane, K., Dionnet, F., Desbène, P., 2008. Optimisation of the extraction of polycyclic aromatic hydrocarbons and their nitrated derivatives from diesel particulate matter using microwave-assisted extraction. Analytical and Bioanalytical Chemistry 390, 389-398.

Ran, Y., Sun, K., Ma, X., Wang, G., Grathwohl, P., Zeng, E.Y., 2007. Effect of condensed organic matter on solvent extraction and aqueous leaching of polycyclic aromatic hydrocarbons in soils and sediments. Environmental Pollution 148, 529-538.

Regonne, R.K., Martin, F., Mbawala, A., Ngassoum, M.B., Jouanneau, Y., 2013. Identification of soil bacteria able to degrade phenanthrene bound to a hydrophobic sorbent in situ. Environmental Pollution 180, 145-151.

Resnick, S.M., Gibson, D.T., 1996. Regio-and stereospecific oxidation of fluorene, dibenzofuran, and dibenzothiophene by naphthalene dioxygenase from Pseudomonas sp. strain NCIB 9816-4. Applied and Environmental Microbiology 62, 4073-4080.

Riding, M.J., Doick, K.J., Martin, F.L., Jones, K.C., Semple, K.T., 2013. Chemical measures of bioavailability/bioaccessibility of PAHs in soil: fundamentals to application. Journal of Hazardous Materials 261, 687-700.

Rouse, J.D., Sabatini, D.A., Suflita, J.M., Harwell, J.H., 1994. Influence of surfactants on microbial degradation of organic compounds. Critical Reviews in Environmental Science and Technology 24, 325-370.

Schloss, P.D., Gevers, D., Westcott, S.L., 2011. Reducing the effects of PCR amplification and sequencing artifacts on 16S rRNA-based studies. PloS one 6, e27310. 
Sebag, D., Disnar, J.R., Guillet, B., Di Giovanni, C., Verrecchia, E.P., Durand, A., 2006. Monitoring organic matter dynamics in soil profiles by 'Rock-Eval pyrolysis': bulk characterization and quantification of degradation. European Journal of Soil Science 57, 344-355.

Semple, K.T., Doick, K.J., Jones, K.C., Burauel, P., Craven, A., Harms, H., 2004. Peer reviewed: defining bioavailability and bioaccessibility of contaminated soil and sediment is complicated. Environmental Science \& Technology 38, 228A-231A.

Semple, K.T., Morriss, A.W.J., Paton, G.I., 2003. Bioavailability of hydrophobic organic contaminants in soils: fundamental concepts and techniques for analysis. European Journal of Soil Science 54, 809-818.

Seo, J.S., Keum, Y.S., Li, Q.X., 2009. Bacterial degradation of aromatic compounds. International Journal of Environmental Research and Public Health 6, 278-309.

Shepard, F.P., 1954. Nomenclature based on sand-silt-clay ratios. Journal of Sedimentary Research 24.

Simarro, R., Gonzalez, N., Bautista, L. F., Sanz, R., and Molina, M. C., 2011. Optimisation of key abiotic factors of PAH (naphthalene, phenanthrene, and anthracene) biodegradation process by a bacterial consortium. Water, Air, \& Soil Pollution 217, 365-374.

Singleton, D.R., Dickey, A.N., Scholl, E.H., Wright, F.A., Aitken, M.D., 2015. Complete genome sequence of a novel bacterium within the family Rhodocyclaceae that degrades polycyclic aromatic hydrocarbons. Genome Announcements 3, e00251-00215.

Singleton, D.R., Sangaiah, R., Gold, A., Ball, L.M., Aitken, M.D., 2006. Identification and quantification of uncultivated Proteobacteria associated with pyrene degradation in a bioreactor treating PAH-contaminated soil. Environmental Microbiology 8, 1736-1745.

Szulc, A., Ambrożewicz, D., Sydow, M., Ławniczak, Ł., Piotrowska-Cyplik, A., Marecik, R., Chrzanowski, Ł., 2014. The influence of bioaugmentation and biosurfactant addition on 
bioremediation efficiency of diesel-oil contaminated soil: Feasibility during field studies. Journal of Environmental Management 132, 121-128.

Teng, Y., Luo, Y., Ping, L., Zou, D., Li, Z., Christie, P., 2010. Effects of soil amendment with different carbon sources and other factors on the bioremediation of an aged PAHcontaminated soil. Biodegradation 21, 167-78.

Thion, C., Cébron, A., Beguiristain, T., Leyval, C., 2013. Inoculation of PAH-degrading strains of Fusarium solani and Arthrobacter oxydans in rhizospheric sand and soil microcosms: microbial interactions and PAH dissipation. Biodegradation 24, 569-581.

745

Tiehm, A., 1994. Degradation of polycyclic aromatic hydrocarbons in the presence of synthetic surfactants. Applied and Environmental Microbiology 60, 258-263.

Timmis, K.N., McGenity, T., Van Der Meer, J., De Lorenzo, V., 2010. Handbook of hydrocarbon and lipid microbiology. Springer Berlin.

Tobiszewski, M., Namieśnik, J., 2012. PAH diagnostic ratios for the identification of pollution emission sources. Environmental Pollution 162, 110-119.

Tsomides, H.J., Hughes, J.B., Thomas, J.M., Ward, C.H., 1995. Effect of surfactant addition on phenanthrene biodegradation in sediments. Environmental Toxicology and Chemistry 14, 953-959.

Uhlik, O., Wald, J., Strejcek, M., Musilova, L., Ridl, J., Hroudova, M., Vlcek, C., Cardenas, E., Mackova, M., Macek, T., 2012. Identification of bacteria utilizing biphenyl, benzoate, and naphthalene in long-term contaminated soil. PloS one 7, e40653.

Wu, Y., Luo, Y., Zou, D., Ni, J., Liu, W., Teng, Y., Li, Z., 2008. Bioremediation of polycyclic aromatic hydrocarbons contaminated soil with Monilinia sp.: degradation and microbial community analysis. Biodegradation 19, 247-257.

Xia, X., Li, Y., Zhou, Z., Feng, C., 2010. Bioavailability of adsorbed phenanthrene by black carbon and multi-walled carbon nanotubes to Agrobacterium. Chemosphere 78, 1329-1336. 
Zhou, J., Jiang, W., Ding, J., Zhang, X., Gao, S., 2007. Effect of Tween 80 and $\beta$-cyclodextrin on degradation of decabromodiphenyl ether (BDE-209) by White Rot Fungi. Chemosphere

764 $70,172-177$.

765 Zhou, W., Zhu, L., 2007. Efficiency of surfactant-enhanced desorption for contaminated soils 766 depending on the component characteristics of soil-surfactant-PAHs system. Environmental $767 \quad$ Pollution $147,66-73$.

768

Zhou, W., Zhu, L., 2008. Enhanced soil flushing of phenanthrene by anionic-nonionic mixed 769 surfactant. Water Research 42, 101-108.

770 
TABLE 1: Physico-chemical properties of the two studied soils (Pv and PPY).

\begin{tabular}{|c|c|c|c|}
\hline Method & Data & PPY & Pv \\
\hline \multirow{8}{*}{$\begin{array}{c}\text { Granulometry without } \\
\text { decarbonatation } \\
\text { (\% dry weight) }\end{array}$} & Clays $(<2 \mu m)$ & 15.5 & 20.2 \\
\hline & Fine silts $(2<D<20 \mu \mathrm{m})$ & 23.4 & 26.0 \\
\hline & Coarse silts $(20<D<50 u m)$ & 42.3 & 442 \\
\hline & Fine sands $(50<D<200$ um $)$ & 178 & 95 \\
\hline & & & \\
\hline & Coarse sands $(200<D<2000$ & & \\
\hline & & 1.0 & 0.1 \\
\hline & $\mu m)$ & & \\
\hline \multirow{5}{*}{ XRD $\left(\right.$ g.kg $\left.{ }^{-1}\right)$} & Chlorite & 36.5 & 0.0 \\
\hline & Illite / Chlorite & 11.2 & 0.0 \\
\hline & Illite & 53.7 & 44.8 \\
\hline & Kaolinite & 53.6 & 66.8 \\
\hline & Smectite & 0.0 & 90.4 \\
\hline \multirow{6}{*}{$\begin{array}{l}\text { RockEval6 Pyrolysis \& S2 } \\
\text { peak deconvolution a }^{\text {a }}\left(\mathrm{g.kg}^{-1}\right)\end{array}$} & Total Organic Carbon (TOC) & 18.7 & 13.1 \\
\hline & Pyrolysable carbon $(P C)$ & 4.2 & 2.6 \\
\hline & Residual carbon $(R C)$ & 14.5 & 10.6 \\
\hline & Biomacromolecules & 8.2 & 4.5 \\
\hline & Immature geomacromolecules & 5.4 & 2.4 \\
\hline & Mature geomacromolecules & 5.1 & 6.2 \\
\hline \multicolumn{2}{|l|}{$p \mathrm{H}\left(\mathrm{H}_{2} \mathrm{O}\right)$} & 5.7 & 8.2 \\
\hline \multicolumn{2}{|c|}{ Cationic Exchange Capacity CEC (cmol. $\left.\mathrm{kg}^{-1}\right)$} & 8.7 & 14.2 \\
\hline \multirow{3}{*}{ PAHs (mg.kg-1) } & $16 P A H s(U S-E P A)$ & $0.320 \pm 0.040$ & $0.890 \pm 0.290$ \\
\hline & & $0.019 \pm 0.006$ & $0.046 \pm 0.022$ \\
\hline & & $0.035 \pm 0.012$ & $0.013 \pm 0.001$ \\
\hline
\end{tabular}

$773{ }^{a}$ The deconvolution of $S 2$ peak, which can be related to soil OM (cracking between 200 to

$\left.774650^{\circ} \mathrm{C}\right)$, allowed a precise determination of the maturation of OM in soils. 
formed at $97 \%$ similarity.

\begin{tabular}{|c|c|c|c|c|c|c|c|c|c|}
\hline \multirow{2}{*}{ Samples ${ }^{b}$} & \multicolumn{9}{|c|}{$0.03^{c}$} \\
\hline & \multicolumn{3}{|c|}{ OTU } & \multicolumn{3}{|c|}{ Chao1 } & \multicolumn{3}{|c|}{$\mathrm{H}^{\prime}$} \\
\hline $\mathrm{Pv}^{\mathrm{d}, \mathrm{x}}$ & 446 & \pm & 105 & 1194 & \pm & 139 & 6.19 & \pm & 0.33 \\
\hline $\mathrm{Pv}{ }_{2} 12 \mathrm{C} \_\mathrm{Rh}+\mathrm{L}^{\mathrm{x}}$ & 417 & \pm & 64 & 1031 & \pm & 124 & 5.75 & \pm & 0.42 \\
\hline $\mathrm{Pv} \_12 \mathrm{C} \_\mathrm{Rh}+\mathrm{H}^{\mathrm{x}}$ & 376 & \pm & 59 & 840 & \pm & 114 & 5.34 & \pm & 0.59 \\
\hline Pv_12C_Rh-_L ${ }^{x}$ & 411 & \pm & 135 & 965 & \pm & 356 & 5.75 & \pm & 0.67 \\
\hline Pv_12C_Rh-_H ${ }^{x}$ & 423 & \pm & 148 & 1000 & \pm & 348 & 5.76 & \pm & 0.82 \\
\hline$P v \_13 C \_R h+L^{x}$ & 417 & \pm & 12 & 1028 & \pm & 48 & 5.78 & \pm & 0.04 \\
\hline $\mathrm{Pv} \_13 \mathrm{C} \_\mathrm{Rh}+\mathrm{H}^{\mathrm{y}}$ & 54 & \pm & 1 & 195 & \pm & 16 & 1.72 & \pm & 0.06 \\
\hline Pv_13C_Rh-_L ${ }^{x}$ & 452 & \pm & 6 & 1143 & \pm & 59 & 5.94 & \pm & 0.04 \\
\hline Pv_13C_Rh-_H ${ }^{y}$ & 40 & \pm & 3 & 137 & \pm & 28 & 1.62 & \pm & 0.19 \\
\hline $\mathrm{PPY}^{\mathrm{d}, \mathrm{x}}$ & 413 & \pm & 20 & 880 & \pm & 61 & 5.82 & \pm & 0.09 \\
\hline PPY_12C_Rh+_L ${ }^{x}$ & 310 & \pm & 61 & 632 & \pm & 123 & 5.17 & \pm & 0.57 \\
\hline PPY_12C_Rh+_H ${ }^{\mathrm{x}}$ & 334 & \pm & 107 & 668 & \pm & 220 & 5.25 & \pm & 0.70 \\
\hline PPY_12C_Rh-_L ${ }^{x}$ & 347 & \pm & 31 & 741 & \pm & 82 & 5.45 & \pm & 0.19 \\
\hline PPY_12C_Rh-_H & 319 & \pm & $N A^{e}$ & 597 & \pm & $N A^{e}$ & 5.04 & \pm & $N A^{e}$ \\
\hline PPY_13C_Rh+_L ${ }^{x}$ & 347 & \pm & 4 & 738 & \pm & 23 & 5.47 & \pm & 0.02 \\
\hline PPY_13C_Rh+_H ${ }^{z}$ & 171 & \pm & 59 & 406 & \pm & 136 & 3.65 & \pm & 0.92 \\
\hline PPY_13C_Rh-_L ${ }^{x}$ & 335 & \pm & 61 & 710 & \pm & 122 & 5.34 & \pm & 0.47 \\
\hline PPY_13C_Rh-_H ${ }^{z}$ & 241 & \pm & 67 & 609 & \pm & 189 & 4.22 & \pm & 0.56 \\
\hline
\end{tabular}

${ }^{\mathrm{a}} \mathrm{x}, \mathrm{y}$ and $\mathrm{z}$ represent the different groups characterized statistically ( $\mathrm{p}<0.05$, Kruskall Wallis test)

${ }^{\mathrm{b}} \mathrm{Rh}^{+/}$: with or without rhamnolipid addition; L/H: light or heavy DNA fractions.

${ }^{\mathrm{c}} 0.03$ is the OTU cutoff in distance units, OTU means the number of OTUs observed, Chao1 means the Chao 1 estimated minimum number of OTUs and $\mathrm{H}^{\prime}$ means the nonparametric Shannon diversity index.

d Soil before spiking

${ }^{\mathrm{e}}$ Not Applicable, for samples with not enough reads for calculation of standard deviation with triplicates. 
785 TABLE 3: Active ${ }^{13} \mathrm{C}$-labeled PHE degraders in the two studied soils (Pv and PPY). OTUs 786 were considered as PHE-degraders when a significantly higher proportion was recovered in heavy DNA fractions from ${ }^{13} \mathrm{C}$ microcosms than from ${ }^{12} \mathrm{C}$ microcosms.

\begin{tabular}{|c|c|c|c|c|c|c|}
\hline \multirow[b]{2}{*}{ Soil } & \multirow[b]{2}{*}{ OTU } & \multicolumn{2}{|c|}{ Taxonomic identification } & \multicolumn{3}{|c|}{ Relative abundance of this OTU found (\%) } \\
\hline & & Phylum / Class & Best resolution $^{\mathrm{a}}$ & $\begin{array}{c}\text { With } \\
\text { Rhamnolipids }\end{array}$ & $\begin{array}{c}\text { Without } \\
\text { Rhamnolipids }\end{array}$ & Native soil \\
\hline \multirow[t]{6}{*}{$\mathrm{Pv}$} & $P v_{-} P H E 1$ & Betaproteobacteria & $\begin{array}{l}\text { Rhodocyclacae } \\
\text { family }\end{array}$ & $52.48 \pm 2.91$ & $50.06 \pm 11.22$ & $0.01 \pm 0.01$ \\
\hline & $P v_{-} P H E 2$ & Betaproteobacteria & $\begin{array}{l}\text { Rhodocyclacae } \\
\text { family }\end{array}$ & $19.77 \pm 1.44$ & $17.95 \pm 3.9$ & $<0.01$ \\
\hline & $P v_{-} P H E 3$ & Betaproteobacteria & $\begin{array}{l}\text { Rhodocyclacae } \\
\text { family }\end{array}$ & $15.69 \pm 2.02$ & $13.69 \pm 2.42$ & $<0.01$ \\
\hline & $P v_{-} P H E 4^{b}$ & Betaproteobacteria & Rhodoferax & $3.16 \pm 2.9$ & $12.02 \pm 8.28$ & $0.12 \pm 0.05$ \\
\hline & Pv_PHE5 & Betaproteobacteria & Hydrogenophaga & $0.76 \pm 0.08$ & $1.11 \pm 1.3$ & $0.03 \pm 0.04$ \\
\hline & $P v_{-} P H E \sigma^{c}$ & Betaproteobacteria & Polaromonas & $0.89 \pm 0.44$ & $0.15 \pm 0.13$ & $0.02 \pm 0.03$ \\
\hline \multirow[t]{13}{*}{ PPY } & PPY_PHE1 & Gammaproteobacteria & Nevskia & $23.90 \pm 18.53$ & $23.92 \pm 11.07$ & $<0.01$ \\
\hline & $P P Y \_P H E 2$ & Betaproteobacteria & $\begin{array}{l}\text { Burkholderiales } \\
\text { order }\end{array}$ & $11.61 \pm 10.5$ & $6.31 \pm 2.57$ & $0.01 \pm 0.02$ \\
\hline & PPY_PHE3 & Betaproteobacteria & Collimonas & $2.13 \pm 0.82$ & $7.89 \pm 6.53$ & $0.29 \pm 0.2$ \\
\hline & PPY_PHE4 & Alphaproteobacteria & $\begin{array}{l}\text { Hyphomicrobiaceae } \\
\text { family }\end{array}$ & $6.22 \pm 3.91$ & $2.55 \pm 1.09$ & $0.25 \pm 0.12$ \\
\hline & PPY_PHE5 & Gammaproteobacteria & Dyella & $4.86 \pm 2.53$ & $3.53 \pm 2.57$ & $0.04 \pm 0.03$ \\
\hline & $P P Y_{-} P H E 6^{c}$ & Betaproteobacteria & Polaromonas & $6.59 \pm 4.59$ & $1.11 \pm 0.22$ & $<0.01$ \\
\hline & PPY_PHE7 & Alphaproteobacteria & $\begin{array}{c}\text { Hyphomicrobiaceae } \\
\text { family }\end{array}$ & $2.30 \pm 0.9$ & $3.12 \pm 3.83$ & $0.03 \pm 0.06$ \\
\hline & PPY_PHE8 & Gammaproteobacteria & Nevskia & $0.91 \pm 0.55$ & $1.60 \pm 2.24$ & $<0.01$ \\
\hline & PPY_PHE9 & Alphaproteobacteria & $\begin{array}{l}\text { Acetobacteraceae } \\
\text { family }\end{array}$ & $1.51 \pm 0.47$ & $1.49 \pm 1.19$ & $<0.01$ \\
\hline & PPY_PHE10 & Actinobacteria & Mycobacterium & $2.04 \pm 1.96$ & $0.73 \pm 0.46$ & $<0.01$ \\
\hline & PPY_PHE11 & Betaproteobacteria & Herbaspirillum & $0.93 \pm 1.20$ & $1.17 \pm 0.76$ & $<0.01$ \\
\hline & $P P Y_{-} P H E 12^{b, c}$ & Betaproteobacteria & Rhodoferax & $1.40 \pm 0.15$ & $0.37 \pm 0.64$ & $0.10 \pm 0.09$ \\
\hline & $P P Y_{-} P H E 13$ & Gammaproteobacteria & Nevskia & $0.46 \pm 0.46$ & $1.21 \pm 1.52$ & $<0.01$ \\
\hline
\end{tabular}


${ }^{\mathrm{b}}$ The two OTUs Pv_PHE4 and PPY_PHE12 are similar

790
791

${ }^{c}$ These OTUs showed significant difference between microcosms with and without rhamnolipids $(\mathrm{P}<0.05$,

792 Student's $t$ test)

793 
795

796

797

798

799

800

801

802

803

804

805

806

807

808

809

810

811

812

813

814

FIG 1: Phenanthrene sorption isotherms (expressed as the quantity of PHE adsorbed on the solid phase $\mathrm{Q}_{\mathrm{ads}}$, relative to the concentration of PHE in solution at the equilibrium $\mathrm{C}_{\mathrm{eq}}$ ) at $25^{\circ} \mathrm{C}$ with and without rhamnolipids $\left(0.55\right.$ g.L $\left.\mathrm{L}^{-1}\right)$ for (a) PPY soil and (b) Pv soil.

FIG 2: PHE degradation on PPY and Pv soils in the presence (at $300 \mathrm{mg} \cdot \mathrm{kg}^{-1}$ ) and absence of rhamnolipids in microcosms spiked with ${ }^{13} \mathrm{C}$ PHE (at $300 \mathrm{mg} \cdot \mathrm{kg}^{-1}$ ). DT20 and DT90 corresponding respectively to $20 \%$ and $90 \%$ of PHE dissipation are represented for both soils.

FIG 3: Quantification of bacterial 16S rRNA gene copies in the 12 fractions separated by $\mathrm{CsCl}$ gradients using real-time quantitative PCR. Data are presented for the two studied soils (PPY and Pv) with and without rhamnolipids and at DT90. Fractions $\mathrm{n}^{\circ} 3$ and $\mathrm{n}^{\circ} 7$ were selected for light DNA and heavy DNA sequencing and analyses, respectively.

FIG 4: Factorial correspondence analysis (FCA) of the relative proportion of the main OTUs (top 100) present in the (a) PPY and (b) Pv samples. Full-tone graphic patterns correspond to microcosms with rhamnolipids. For each soil type the principal component axes F1 and F2 explain most of the variance in the data cumulatively. 


\section{$815 \quad$ Figure 1}

816

817
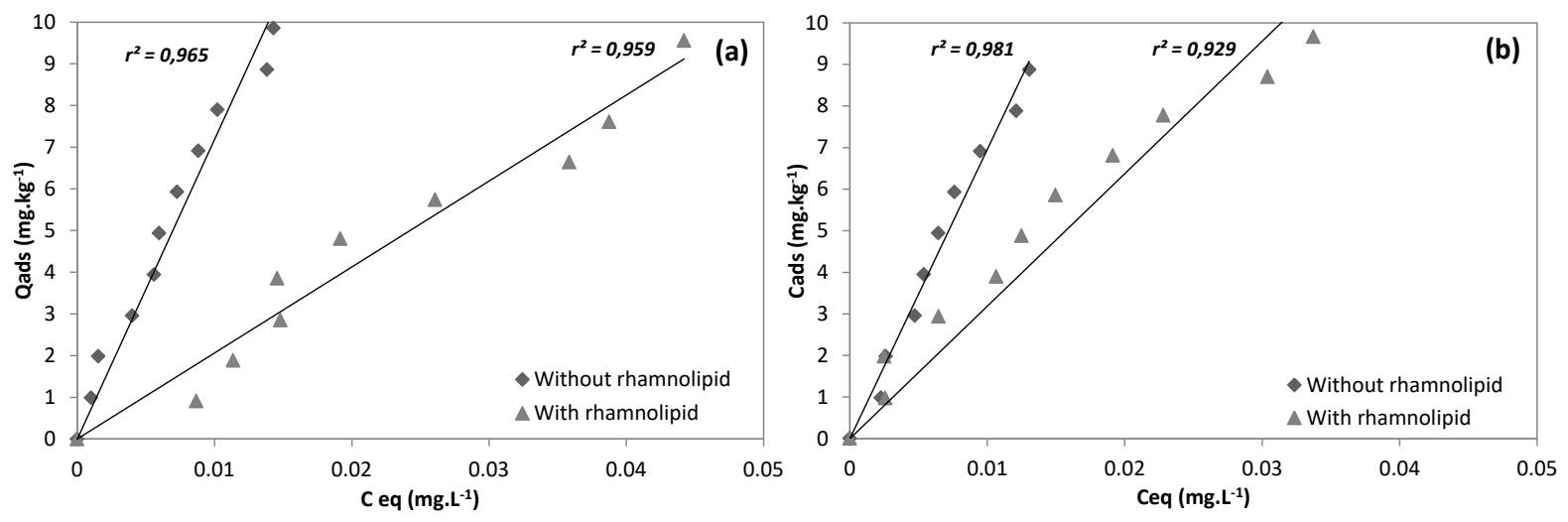

818 
Figure 2

820

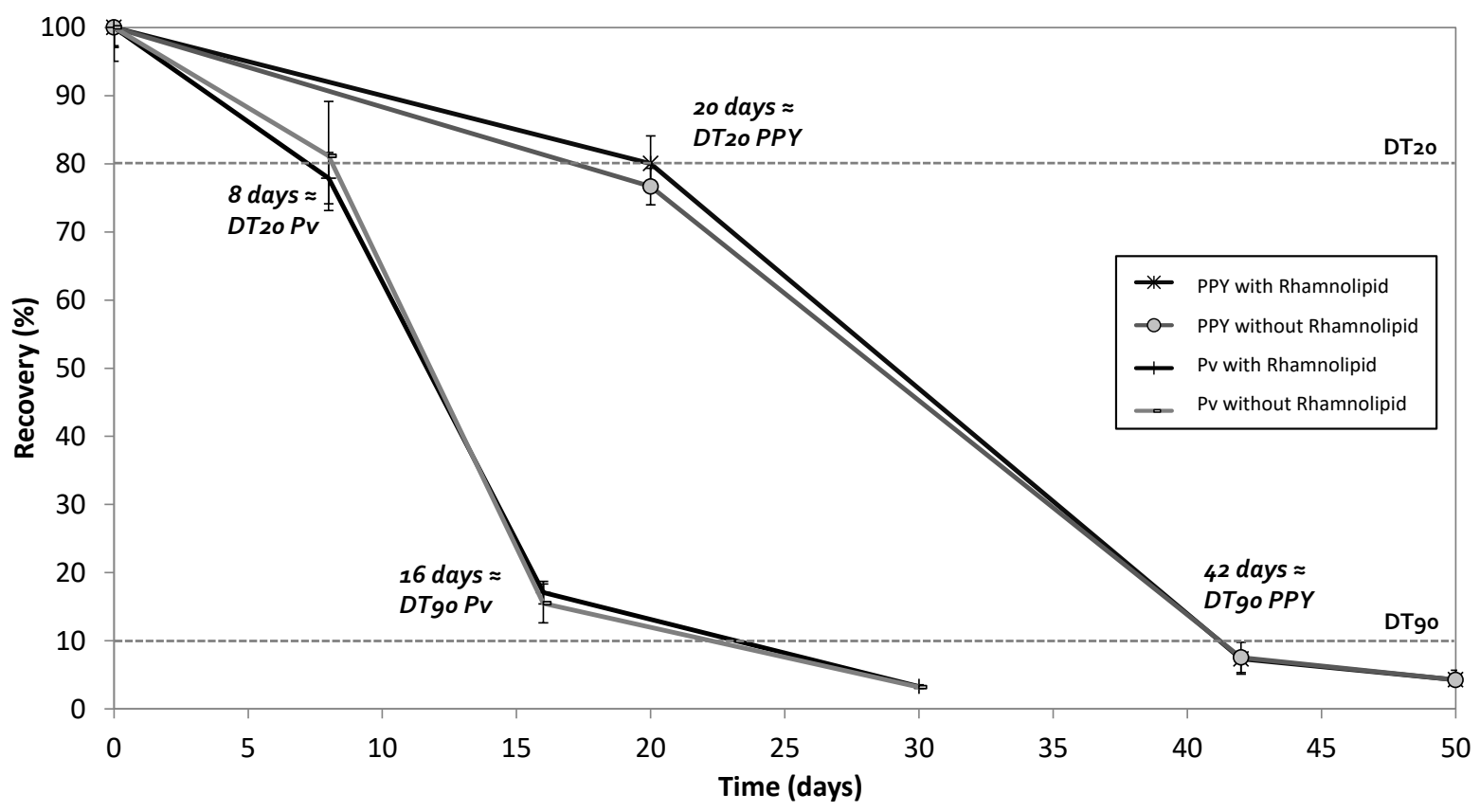

821

822 
824

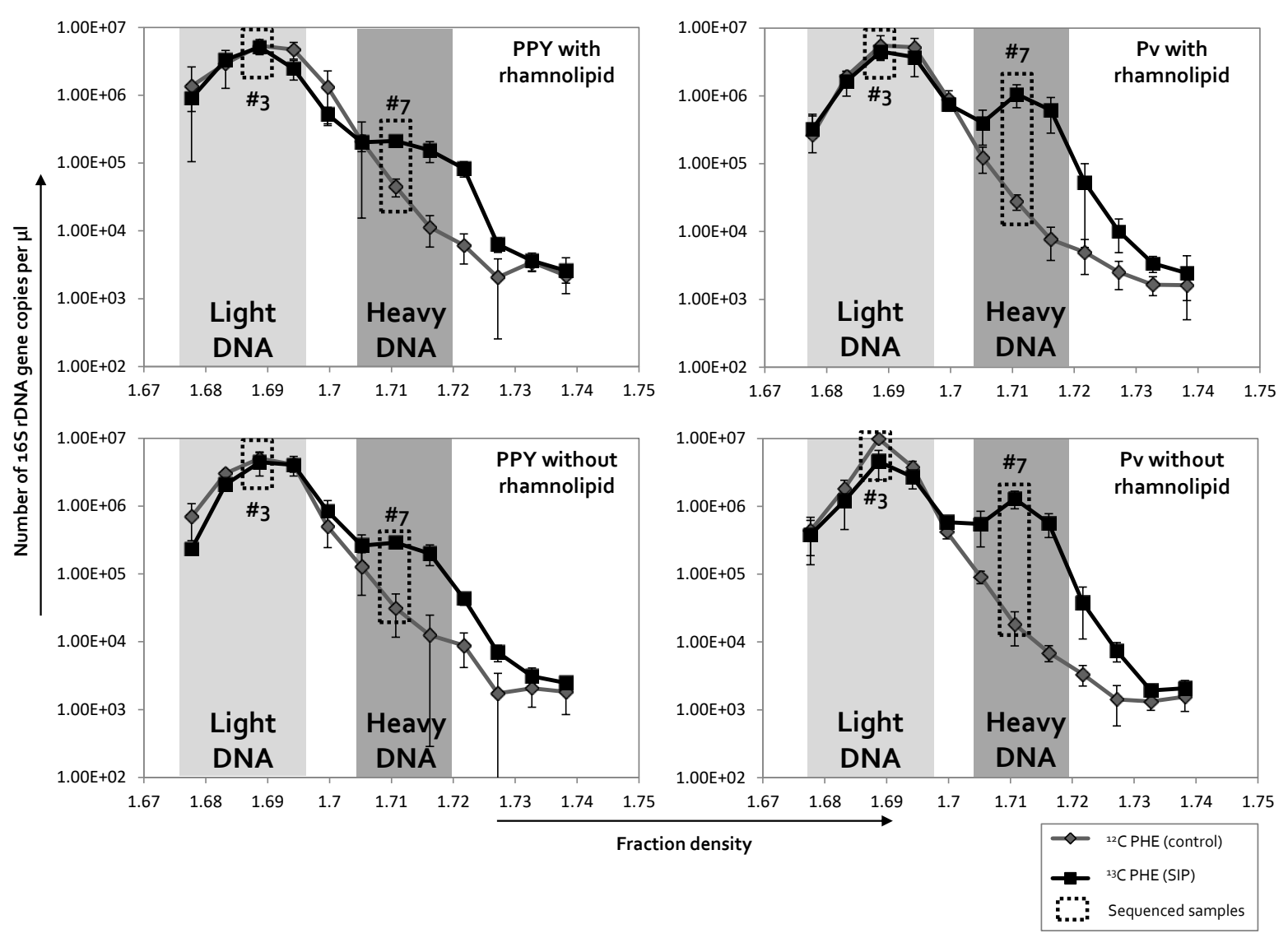



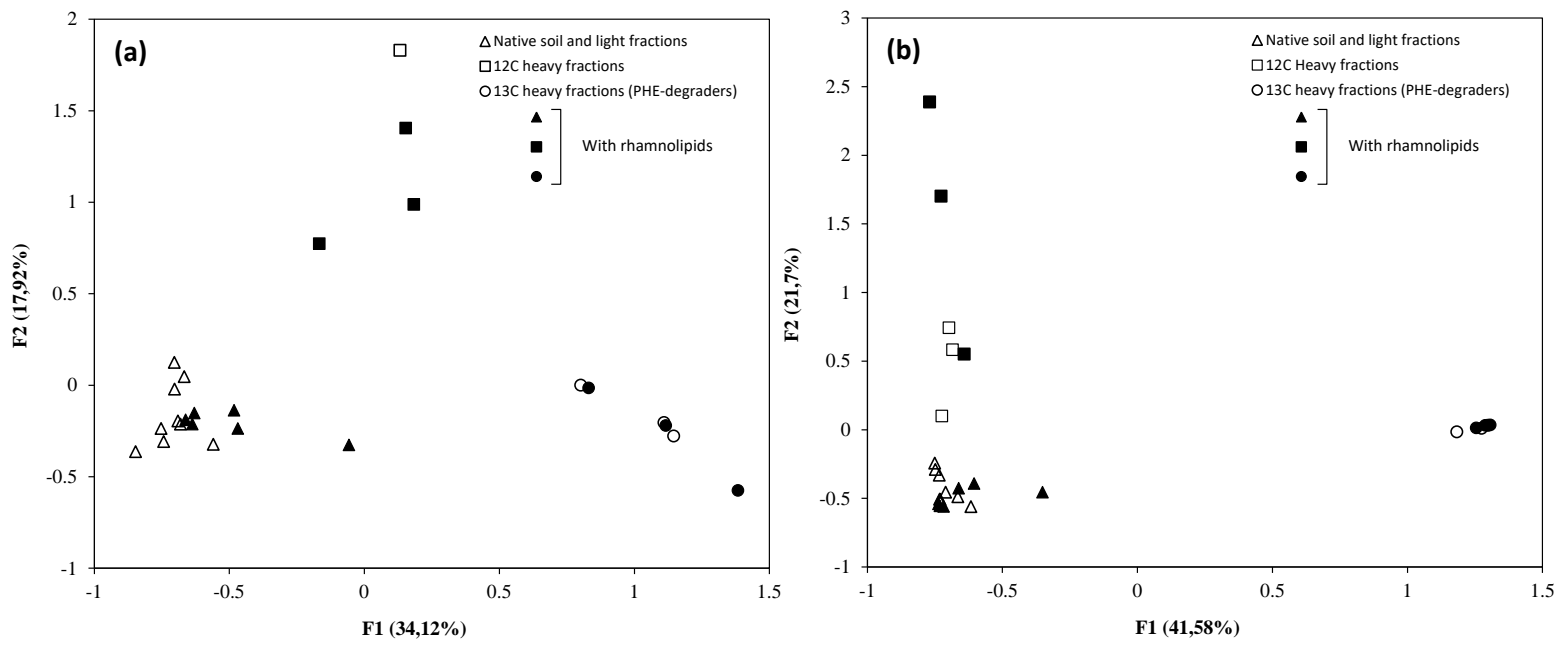

830

831 


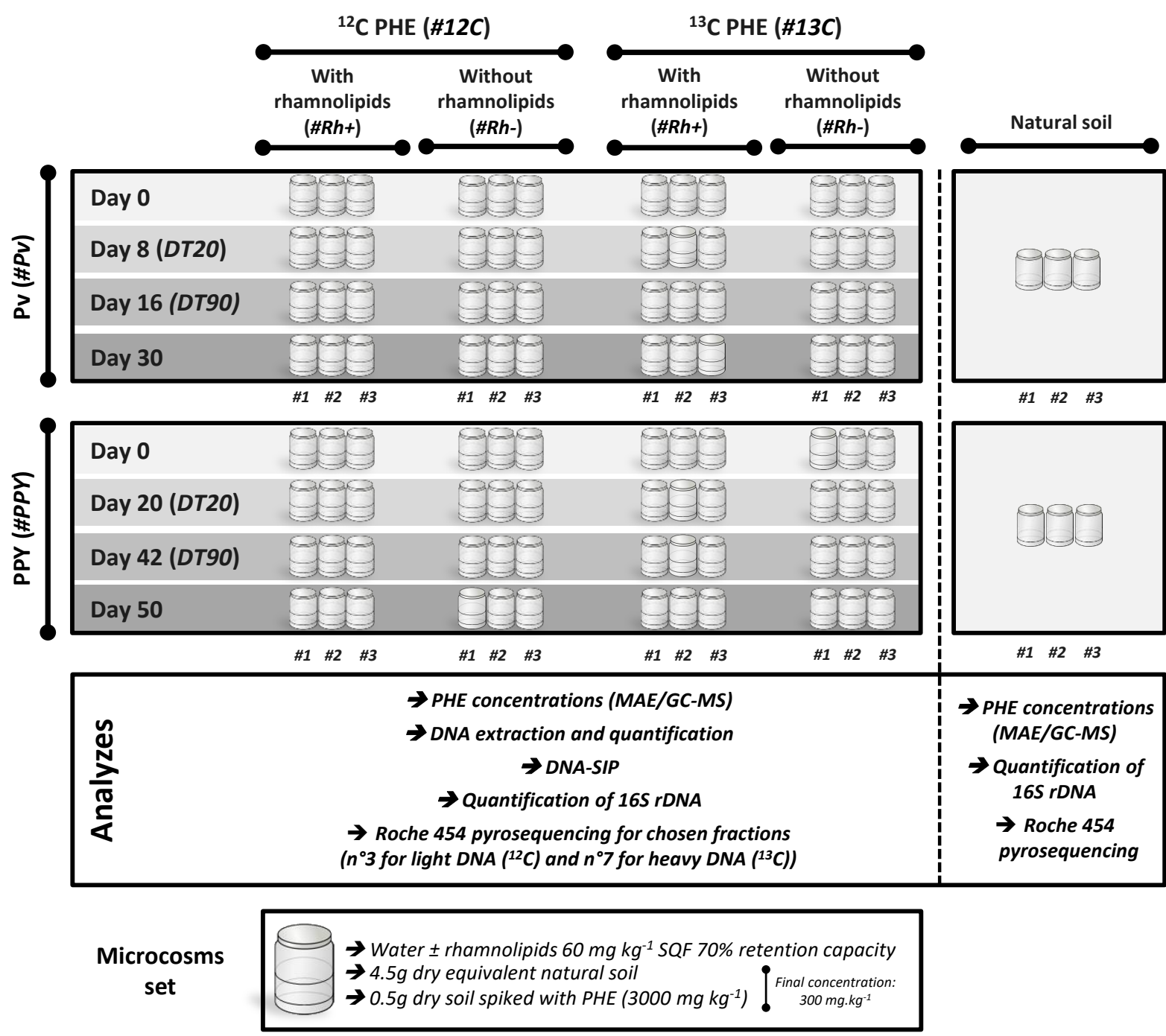

834 FIG S1: Experimental set up corresponding to the phenanthrene-contaminated microcosms. 


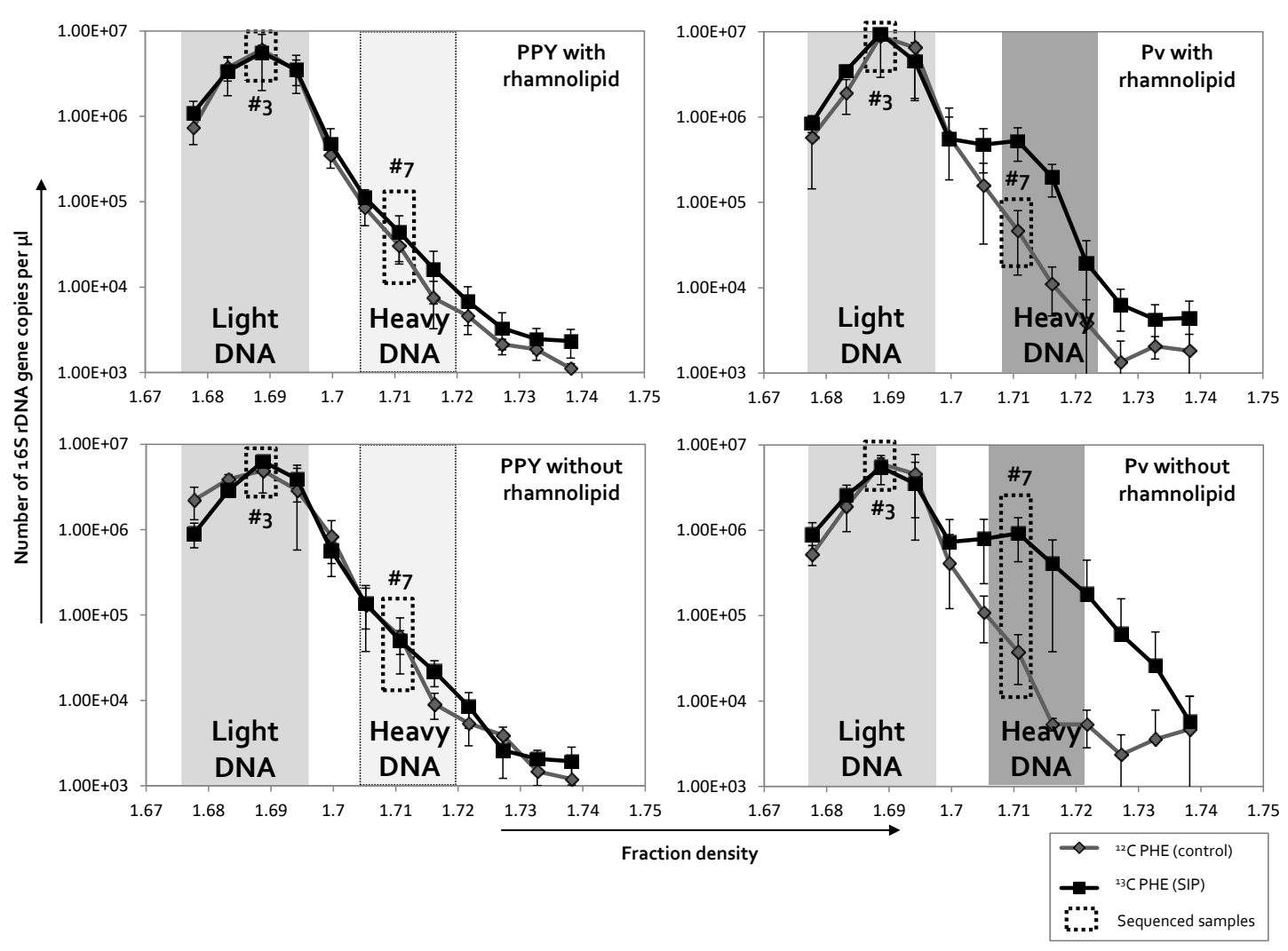

841 gradients using real-time quantitative PCR. Data are presented for the two studied soils (PPY 842 and $\mathrm{Pv}$ ) with and without rhamnolipids and at DT20. Fractions $\mathrm{n}^{\circ} 3$ and $\mathrm{n}^{\circ} 7$ were selected as 843 models for light DNA and heavy DNA containing fractions, respectively. 

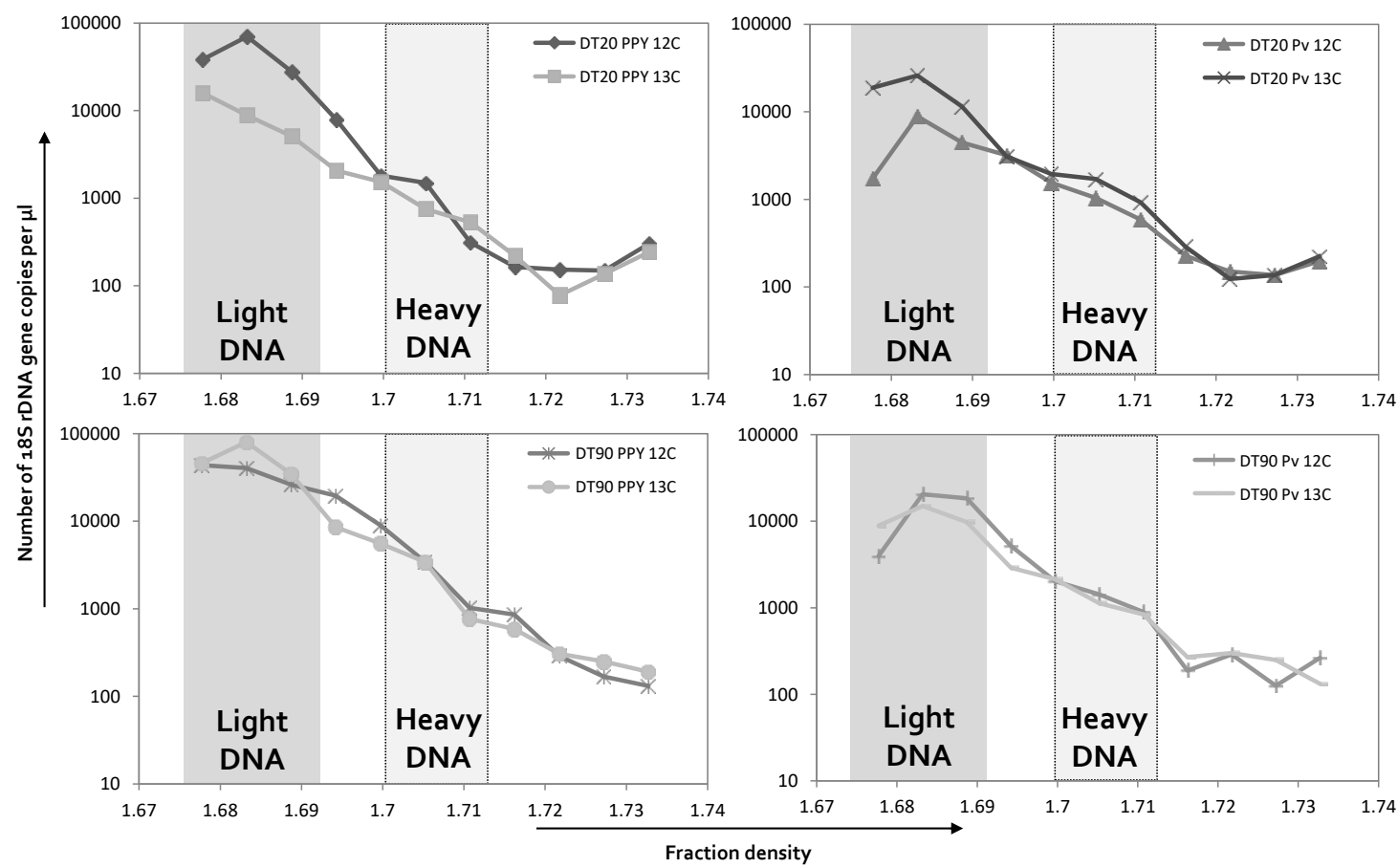

846

847 FIG S3: Quantification of fungal 18S rRNA gene copies in the 12 fractions separated by $\mathrm{CsCl}$

848 gradients using real-time quantitative PCR. Data are presented for the two studied soils (PPY

849 and Pv) with rhamnolipids, at DT20 and DT90, only for one replicate. 


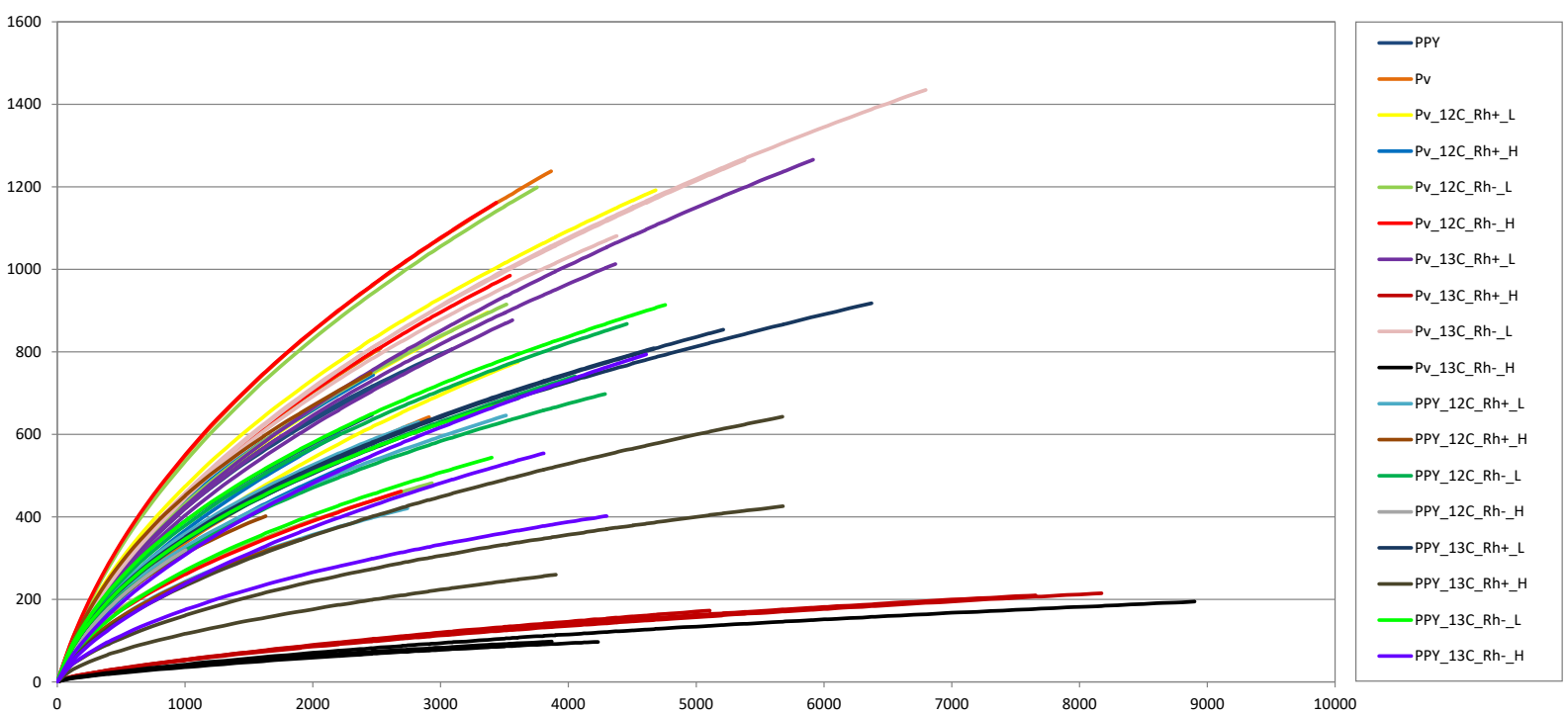

853 FIG S4: Rarefaction curves based on OTU at 97\% similarity. Sequencing of 16S rDNA from

854 light (L) and heavy (H) DNA fractions ( $\mathrm{n}^{\circ} 3$ and $\mathrm{n}^{\circ} 7$, respectively) isolated from soils $(\mathrm{Pv}$ and

855 PPY) incubated with ${ }^{12} \mathrm{C}$ or ${ }^{13} \mathrm{C}$-PHE, and with and without rhamnolipids (Rh+ and $\left.\mathrm{Rh}-\right)$. For 856 each sample, triplicates are represented.

857 


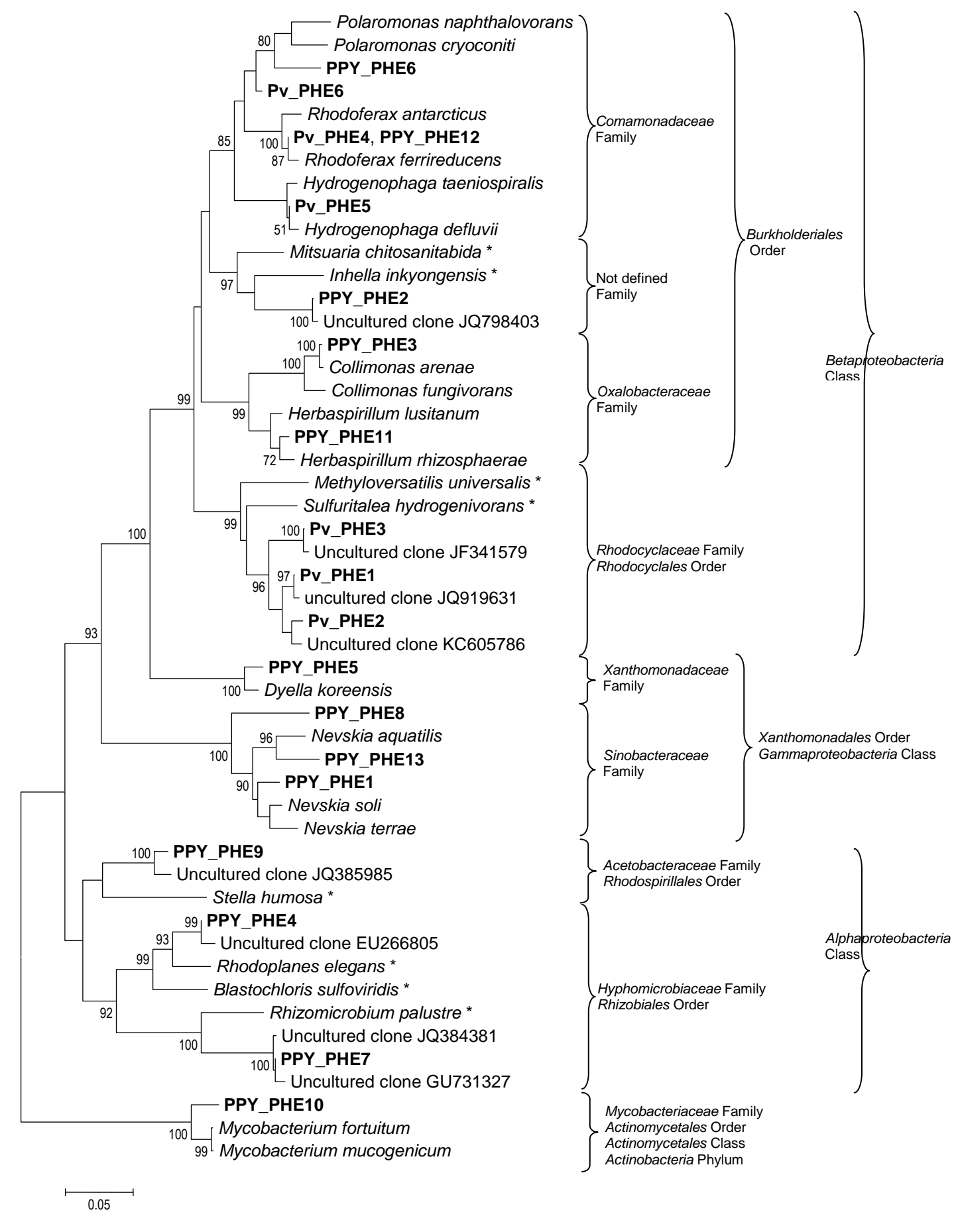

860 FIG S5: 16S rRNA gene phylogeny of the dominant PHE-degrading bacteria from soil 861 microcosms enriched with PHE. Sequences of closest relative bacteria are included in the 862 analysis. The unrooted dendrogram was generated using neighbor joining analysis. The scale 863 bar corresponds to 0.05 substitutions per nucleotide position. Numbers on tree branches indicate 864 bootstrap for those branches having $>80 \%$ support. Sequences provided in this study are in 865 bold. 
